\title{
Behaviour of chromium and chromium isotopes during estuarine mixing in the
}

\section{Beaulieu Estuary, UK}

Heather J. Goring-Harford ${ }^{1 \star}$, Jessica K. Klar²,3, Hannah K. Donald ${ }^{1}$, Christopher R. Pearce ${ }^{4}$, Douglas P. Connelly ${ }^{4}$, Rachael H. James ${ }^{1}$

${ }^{1}$ School of Ocean and Earth Science, National Oceanography Centre, University of Southampton Waterfront Campus, Southampton, SO14 3ZH, UK.

2Université de Perpignan Via Domitia, Centre de Formation et de Recherche sur les Environnements Méditerranéens (CEFREM), UMR 5110, 52 Avenue Paul Alduy, F-66860 Perpignan Cedex, France

${ }^{3}$ CNRS, CEFREM, UMR 5110, 52 Avenue Paul Alduy, F-66860 Perpignan Cedex, France

${ }^{4}$ Marine Geoscience, National Oceanography Centre, University of Southampton Waterfront Campus, Southampton, SO14 3HZ, UK.

${ }^{\star}$ Corresponding Author

Email address: h.j.goring-harford@soton.ac.uk 


\section{Abstract}

Rivers are the principal source of chromium $(\mathrm{Cr})$ to seawater and the $\mathrm{Cr}$ isotopic signatures of ancient marine sediments are widely considered to provide a record of the presence or absence of oxidative weathering processes on land. This assumes, however, that the $\delta^{53} \mathrm{Cr}$ value of river water is faithfully transferred to the oceans and is not modified in the estuarine mixing zone. To test this assumption we have determined the concentration and $\delta^{53} \mathrm{Cr}$ values of inorganic $\mathrm{Cr}(\mathrm{Cr}(\mathrm{III})+\mathrm{Cr}(\mathrm{VI}))$, and also $\mathrm{Cr}$ speciation for water samples collected within the estuarine mixing zone of the Beaulieu River, UK. The $\delta^{53} \mathrm{Cr}$ values of dissolved inorganic $\mathrm{Cr}$ ranged from -0.59 to $1.68 \%, \mathrm{Cr}(\mathrm{VI})$ concentrations from 0.39 to $1.83 \mathrm{nmol} \mathrm{kg}^{-1}$ and $\mathrm{Cr}(\mathrm{III})$ concentrations from 0.11 to $3.21 \mathrm{nmol} \mathrm{kg}{ }^{-1}$. Both $\mathrm{Cr}(\mathrm{VI})$ concentrations and $\delta^{53} \mathrm{Cr}$ values increased linearly as a function of salinity, while $\operatorname{Cr}(\mathrm{III})$ concentrations decreased linearly with salinity. Thus $\delta^{53} \mathrm{Cr}, \mathrm{Cr}(\mathrm{III})$ and $\mathrm{Cr}(\mathrm{VI})$ all showed conservative behaviour in the estuarine mixing zone, and the $\delta^{53} \mathrm{Cr}$ signature of Beaulieu River water was modified only by mixing between the river and seawater endmembers. The calculated average $\delta^{53} \mathrm{Cr}$ value of the river water endmember $(-0.39 \pm 0.08 \%)$ was, however, lower than the range that has been observed in other rivers, which we attribute to input of organically-bound $\mathrm{Cr}$ (III) released by anoxic weathering processes. This is supported by the fact that $\mathrm{Cr}$ recovered by UV irradiation was found to have low $\delta^{53} \mathrm{Cr}$ values $(-0.11$ to $-0.75 \%$ ). While input of $\mathrm{Cr}$ from anoxic weathering processes is unlikely to be an important source of $\mathrm{Cr}$ to the oceans today, this suggests that processes other than oxidative weathering may have an influence on the $\delta^{53} \mathrm{Cr}$ values of estuarine and coastal waters on the local scale. The $\delta^{53} \mathrm{Cr}$ value of the coastal seawater endmember $(1.6 \pm 0.4 \%$ o) was also higher than the range observed in the deep open ocean, due to in situ biogeochemical cycling of $\mathrm{Cr}$. These factors need to be considered in the interpretation of marine sedimentary $\delta^{53} \mathrm{Cr}$ records.

Keywords: chromium isotopes, chromium speciation, chromium cycling, estuarine mixing, anoxic weathering 


\section{Introduction}

2 Chromium ( $\mathrm{Cr}$ ) is a redox sensitive element with two stable oxidation states, $\mathrm{Cr}(\mathrm{VI})$ and $\mathrm{Cr}(\mathrm{III})$, at Earth surface conditions. It has four stable isotopes, ${ }^{50} \mathrm{Cr},{ }^{52} \mathrm{Cr},{ }^{53} \mathrm{Cr}$ and ${ }^{54} \mathrm{Cr}$, which can fractionate during oxidation and reduction reactions (Zink et al., 2010; Døssing et al., 2011; Kitchen et al., 2012). Most ground water and seawater samples analysed to date are enriched

6 in heavy $\mathrm{Cr}$ isotopes (i.e. they have relatively high $\delta^{53} \mathrm{Cr}$ values, where

$7 \quad \delta^{53} \mathrm{Cr}=\left(\frac{\left.\left({ }^{53} \mathrm{Cr}{ }^{52} \mathrm{Cr}\right)_{\text {sample }}-\left({ }^{53} \mathrm{Cr}\right)^{52} \mathrm{Cr}\right)_{\mathrm{NBS}} \text { 979 standard }}{}\right) \times 1000$; Ellis et al. 2002; Bonnand et al. 2013;

8 Scheiderich et al. 2015; Holmden et al. 2016; Paulukat et al. 2016; Pereira et al. 2015; Goring-

$9 \quad$ Harford et al. 2018; Moos and Boyle 2018; Bruggmann et al. 2019) compared to crustal rocks $\left(\delta^{53} \mathrm{Cr}=-0.12 \pm 0.10 \%\right.$; Schoenberg et al. 2008). This has been attributed to the preferential release of heavy $\mathrm{Cr}$ isotopes during the oxidative weathering of $\mathrm{Cr}(\mathrm{III})$, followed by transfer of the $\mathrm{Cr}(\mathrm{VI})$ that forms to the oceans via rivers (Frei et al. 2009), and to the preferential removal of light $\mathrm{Cr}$ isotopes during biologically-mediated redox reactions in seawater (Scheiderich et al., 2015; Goring-Harford et al., 2018; Moos and Boyle, 2018).

Records of ancient seawater $\delta^{53} \mathrm{Cr}$ values, preserved in the authigenic fraction of marine sediments, are considered to provide evidence for the evolution of atmospheric oxygen, and consequently life, on Earth (e.g. Frei et al. 2009; Crowe et al. 2013; Planavsky et al. 2014). Critically, this interpretation relies on the assumption that the oxidative weathering signal is faithfully transferred from rivers to seawater, as rivers are the main source of $\mathrm{Cr}$ to the oceans ( $>90 \%$ of the total Cr input; Jeandel and Minster 1987; Bonnand et al. 2013; Reinhard et al. 2013; McClain and Maher 2016; Sun et al. 2019). The $\delta^{53} \mathrm{Cr}$ range previously reported for unpolluted river water is -0.3 to $1.7 \%$ ( $n=49$; Figure 1; Frei et al. 2014; D'Arcy et al. 2016; Wu et al. 2017; Andronikov et al. 2019), which is similar to that of seawater (0.02 to $1.7 \%$; $n=156$; Bonnand et al. 2013; Scheiderich et al. 2015; Holmden et al. 2016; Paulukat et al. 2016; Pereira et al. 2015; Goring-Harford et al. 2018; Moos and Boyle 2018; Bruggmann et al. 2019). However, the mean value for river water $(0.49 \pm 0.45 \%)$ is higher than the mean value for seawater $\left(1.07 \pm 0.35 \%\right.$ ), which implies that $\delta^{53} \mathrm{Cr}$ values may be altered after oxidative 
weathering occurs, for example by redox reactions of $\mathrm{Cr}$ in surface ocean waters (Scheiderich et al., 2015; Goring-Harford et al., 2018; Bruggmann et al., 2019). Although other potential mechanisms for $\mathrm{Cr}$ isotope fractionation in natural waters have yet to be investigated in detail, it is likely that refinements to the model proposed by Frei et al. 2009 are required to properly employ $\mathrm{Cr}$ as a proxy for atmospheric oxygenation (see also Toma et al. 2019).

Fractionation of $\mathrm{Cr}$ isotopes during transport from rivers to the ocean has the potential to significantly modify $\delta^{53} \mathrm{Cr}$ values before preservation in marine sediments (Bonnand et al., 2013; Paulukat et al., 2015; D'Arcy et al., 2016). Rivers typically contain between 2nM and 20nM of dissolved $\mathrm{Cr}$ (e.g. Bonnand et al. 2013 and references therein), though rivers draining mafic lithologies or land contaminated with industrial waste can contain much higher levels (100-2000nM; McClain and Maher 2016; Novak et al. 2014; Paulukat et al. 2015). Chromium(VI) is the thermodynamically stable form of $\mathrm{Cr}$ in oxygen-replete waters (Elderfield, 1970), but rivers commonly contain both $\mathrm{Cr}(\mathrm{III})$ and $\mathrm{Cr}(\mathrm{VI})$ in varying proportions (Cranston and Murray, 1980; Dolamore-Frank, 1984; Kieber and Helz, 1992; Abu-Saba and Flegal, 1995; Gardner and Ravenscroft, 1996; Comber and Gardner, 2003; Saputro et al., 2014; McClain and Maher, 2016), likely due to complexation of $\mathrm{Cr}(\mathrm{III})$ with organic molecules, which stabilises it in solution (Dolamore-Frank, 1984; Kaczynski and Kieber, 1994; Abu-Saba and Flegal, 1995; Buerge and Hug, 1998; Icopini and Long, 2002). Chromium(VI) shows conservative behaviour in many estuaries, meaning its concentration is simply determined by the relative proportion of freshwater to seawater (Cranston and Murray, 1980; Mayer and Schick, 1981; DolamoreFrank, 1984). However, in some estuaries $\mathrm{Cr}(\mathrm{VI})$ appears to be partially reduced to $\mathrm{Cr}(\mathrm{III})$ in the presence of organic molecules or photochemically produced Fe(II) (Kieber and Helz, 1992; Saputro et al., 2014; D'Arcy et al., 2016). The $\operatorname{Cr}(\mathrm{III})$ that is produced can be removed (i) at low salinities due to the flocculation of organic materials (Cranston and Murray, 1980; Mayer and Schick, 1981; Campbell and Yeats, 1984), or (ii) by adsorption onto sedimentary particles (Mayer and Schick, 1981; Abu-Saba and Flegal, 1995; Jonas and Millward, 2010). As Cr(III) is expected to be enriched in lighter isotopes (Ellis et al., 2002; Zink et al., 2010; Døssing et 

al., 2011; Kitchen et al., 2012), this may drive $\delta^{53} \mathrm{Cr}$ values in the remaining $\mathrm{Cr}(\mathrm{VI})$ that is delivered to the oceans to higher values (Bonnand et al., 2013; Paulukat et al., 2015; D'Arcy et al., 2016).

To date, Cr isotope behaviour has only been studied in the Connecticut estuary, USA (Sun et al., 2019). This study revealed that there were no systematic variations in $\delta^{53} \mathrm{Cr}$ (or $\mathrm{Cr}$ concentration) as a function of salinity, although $\mathrm{Cr}$ speciation was not determined. Given the diverse range of $\mathrm{Cr}$ reactions that can occur in estuarine mixing zones, further investigation is needed to assess their potential for modification of $\delta^{53} \mathrm{Cr}$. This study reports the results of a systematic investigation of $\delta^{53} \mathrm{Cr}$ values and $\mathrm{Cr}$ speciation with respect to salinity in the Beaulieu River and estuary (UK).

\section{Sampling location}

The Beaulieu River is located in the New Forest National Park (UK), and drains into the strait between mainland England and the Isle of Wight known as the Solent (Figure 2). The protected status of the National Park means that its catchment is sparsely populated and there is little industry, so levels of pollution in the Beaulieu River are minimal compared to most UK rivers.

The New Forest primarily consists of heathlands, woodlands, bogs and wetlands. Surficial deposits are predominantly the Paleogene Barton and Headon Group sands, although Quaternary alluvia, clays and silts are found around the river and promote the growth of forest patches (Gilkes 1968). There are also tidal flats around the mouth of the estuary. The upper limit of the estuary is marked by a sluice gate, upstream of which is a small lake (the Mill Dam; Figure 2) that sometimes contains a small component of seawater. The depth of the river does not usually exceed $\sim 1 \mathrm{~m}$ whereas the depth of the estuary changes considerably with the state of the tide, varying between $\sim 0.1$ and $4 \mathrm{~m}$. The freshwater residence time in the estuary is $\sim 7$ days (Fang, 1995), which is similar to the residence time of water in the Solent ( -6.25 days; 
81 Concentrations of dissolved oxygen are high (up to $370 \mu \mathrm{mol} \mathrm{L}^{-1}$ ) throughout the river, and $\mathrm{pH}$

82 varies between 6.5 and 7.8 (Hopwood et al. 2014). Due to the nature of the vegetation in the catchment, the river waters have high levels of dissolved organic carbon (DOC), and estuarine waters can have DOC concentrations of $>1 \mathrm{mg} \mathrm{L}^{-1}$ even at high salinities $(S=>24)$ (Moore et al. 1979). Concentrations of dissolved iron (dFe) in the river are highly variable (8-21 $\mu \mathrm{M})$, and they fall significantly as the river water mixes with seawater, because $\mathrm{Fe}$ is incorporated into organic flocculates or forms Fe oxyhydroxide precipitates (Holliday and Liss, 1976; Fang, 1995; Hopwood et al., 2014). Up to $\sim 50 \%$ of Fe at low salinities ( $=<5)$ is present as $\mathrm{Fe}(\mathrm{II})$ (Hopwood et al., 2014), which is an effective reductant for $\mathrm{Cr}(\mathrm{VI})$ (Døssing et al., 2011; Kitchen et al., 2012).

The total dissolved concentration of $\mathrm{Cr}$ in the Solent adjacent to the Beaulieu estuary (also known as Southampton Water) is $\sim 1.3-1.8 \mathrm{nM}$ (Bonnand et al., 2013), although higher concentrations (up to $5 \mathrm{nM}$ ) have been recorded in the Beaulieu River itself (Dolamore-Frank, 1984). In a previous study, dissolved $\mathrm{Cr}$ appeared to behave conservatively during estuarine mixing, although loss of $\mathrm{Cr}(\mathrm{VI})$ from solution was suggested at high salinities, possibly as a result of reduction of $\mathrm{Cr}(\mathrm{VI})$ by $\mathrm{DOC}$ and removal of the $\mathrm{Cr}(\mathrm{III})$ that formed (Dolamore-Frank, 1984). Nevertheless, concentrations of particulate $\mathrm{Cr}$ were low even though dissolved concentrations of $\mathrm{Cr}(\mathrm{III})$ were relatively high, indicating that adsorption of this $\mathrm{Cr}(\mathrm{III})$ onto particulate material was not an important process in the estuary (Dolamore-Frank, 1984). The $\delta^{53} \mathrm{Cr}$ value of total dissolved $\mathrm{Cr}$ in Southampton Water at salinities of 30 and higher appears to be consistent over time at $1.50 \pm 0.02 \%$, $(n=7$; Bonnand et al. 2013; Goring-Harford et al. 2018) though the $\mathrm{Cr}$ isotopic compositions of river and estuarine waters of the Beaulieu have not hitherto been measured.

\section{Methods}

\subsection{Sampling}

All containers and sampling/filtration equipment were acid cleaned before use. A river water endmember sample was taken from the King's Hat Enclosure on $20^{\text {th }}$ March 2016 and the 
estuary was sampled around high tide on $22^{\text {nd }}$ March 2016 from the R.V. Bill Conway. A rigidinflatable boat (RIB) was used to access the shallowest waters, but the low to intermediate salinities $(S=1-14)$ were inaccessible due to low rainfall in the preceding week, and the rapid mixing between freshwater and seawater at the sluice gate. A second set of samples targeting a lower salinity range was therefore taken on $5^{\text {th }}$ October 2016 from the river, Mill Dam and upper part of the estuary waters during the early stages of the flood tide. Rainfall in the week preceding each sampling date were $0.0 \mathrm{~mm}$ for March and $8.8 \mathrm{~mm}$ for October (measured by a Davis Vantage Pro Plus weather station; http://www.tottonweather.co.uk/datasummary/).

All samples were recovered from $0.1-0.5 \mathrm{~m}$ depth below the surface using a $1 \mathrm{~L}$ bottle either by hand or by deploying a weighted metal free bottle holder. The $1 \mathrm{~L}$ aliquots were homogenised in a larger container (5-6L total sample volume) and a subsample of this was taken immediately to measure salinity, $\mathrm{pH}$ and temperature (WTW Measurement Systems Inc. 340i handheld multimeter).

River sediment pore waters were sampled by inserting $80 \mathrm{~mm}$ diameter plastic core liners into the river bed at King's Hat Enclosure in April 2017. Cores were immediately transported back to the National Oceanography Centre Southampton (NOCS) and placed in a constant temperature laboratory at $10^{\circ} \mathrm{C}$ (to approximately match the temperature of the river water) before processing.

\subsection{Determination of $\mathrm{Cr}$ concentration and $\mathrm{Cr}$ isotopic composition of river and} estuarine waters

All acids used in sample processing were thermally distilled, while the other chemicals were Romil UpA, Fluka TraceSELECT Ultra, or Aristar ${ }^{\circledR}$ Ultra grade and contributed negligible $\mathrm{Cr}$ to the total procedural blank.

Water samples were filtered within 24 hours of collection in a class 100 clean laboratory using pre-rinsed Sartorius Sartobran 300 capsule filters $(0.45 \mu \mathrm{m}) . \mathrm{A}^{50} \mathrm{Cr}+{ }^{54} \mathrm{Cr}(\mathrm{III})$ double spike was 
134 added to samples being processed for isotopic analysis to account for any fractionation

135 incurred during sample processing (full details of the spike are given in Goring-Harford et al 136 2018). At least 100ng of $\mathrm{Cr}$, at a concentration of $\sim 30 \mathrm{ppb}$ in the analyte, was required for 137 isotopic analysis. Because the $\mathrm{Cr}$ concentration of river waters and seawater is much lower 138 (typically $\sim 0.1 \mathrm{ppb}$ ), it was necessary to pre-concentrate $\mathrm{Cr}$. To do this we employed a Fe(II) 139 co-precipitation method (Bonnand et al. 2013; Scheiderich et al. 2015; Goring-Harford et al. 140 2018). Samples collected in March 2016 were preserved by acidification to $\mathrm{pH}<2$ using $2 \mathrm{ml}$ $141 \mathrm{~L}^{-1}$ of sub-boiled $\mathrm{HCl}$ prior to $\mathrm{Fe}(\mathrm{II})$ precipitation (except for the aliquots taken for $\mathrm{Cr}(\mathrm{III})$ 142 analysis). The October 2016 samples were precipitated with $\mathrm{Fe}$ (II) on the day of filtration 143 (within $\sim 8$ hours). Both approaches are expected to successfully capture all inorganic $\mathrm{Cr}$, as $144 \mathrm{Cr}(\mathrm{III})$ adsorption to container walls is prevented both by low $\mathrm{pH}$ conditions prior to spiking and by prompt co-precipitation after collection; adsorption is not thought to be important for $\mathrm{Cr}(\mathrm{VI})$ 146 (Gaillardet et al. 2003).

147 The $\mathrm{pH}$ of the river water samples ( $-3 \mathrm{~L}$ volume) was adjusted to $\mathrm{pH}$ 8-9 approximately 24 148 hours after the double spike was added. Total dissolved inorganic chromium $\left(\mathrm{Cr}_{\mathrm{T}}\right.$, defined as $149 \mathrm{Cr}(\mathrm{III})+\mathrm{Cr}(\mathrm{VI})$ ) was then removed from solution using an $\mathrm{Fe}(\mathrm{II})$ hydroxide precipitate (made 150 from $2 \mathrm{mM}$ ammonium Fe(II) sulphate, Sigma-Aldrich batch $04728 \mathrm{LI}, 10 \mathrm{ml} \mathrm{L}^{-1}$ of sample) that converts any $\mathrm{Cr}(\mathrm{VI})$ to $\mathrm{Cr}(\mathrm{III})$ and quantitatively removes the $\mathrm{Cr}(\mathrm{III})$ in the form of a $\mathrm{Fe}(\mathrm{III})$ Cr(III) precipitate (Shigematsu et al., 1977; Cranston and Murray, 1978; Dolamore-Frank, 1984; Jeandel and Minster, 1984). The precipitate was then separated by vacuum filtration using acid cleaned Millipore Omnipore filters $(1 \mu \mathrm{m})$. A two-stage ion exchange chromatography procedure was carried out to remove the Fe and residual salts using the Biorad AG1-X8 and AG50-X12 resins respectively (Bonnand et al., 2013), and any remaining organic material was oxidised using $\mathrm{H}_{2} \mathrm{O}_{2}$. The $\mathrm{Cr}$ isotopic composition of the purified $\mathrm{Cr}$ sample-spike mixture was determined using a Thermo Fisher Neptune multicollector inductively coupled plasma mass spectrometer (MC-ICP-MS) in medium resolution mode. Newton-Raphson deconvolution and isotope dilution calculations were used to calculate 
$161 \delta^{53} \mathrm{Cr}_{\mathrm{T}}$ and $\mathrm{Cr}_{\mathrm{T}}$ respectively. Raw data were corrected for instrumental drift and the total

162 procedural blank contribution, which mainly came from the Fe precipitate and typically 163 constituted $<10 \%$ of the total $\mathrm{Cr}$ analysed (blank $\delta^{53} \mathrm{Cr}_{\mathrm{T}}=-0.34 \pm 0.32 \%$ o $\mathrm{SD}, \mathrm{n}=6$ ). Repeat 164 analyses of the NBS979 standard, normalised to the daily average NBS979 value, yielded an analytical reproducibility of $\pm 0.04 \%$ ( $n=344,2 S D$ ). The external reproducibility of coprecipitated samples, determined from multiple analyses of the OSIL salinity standard $(n=6)$, was better than $\pm 0.11 \%$ (Goring-Harford et al., 2018).

It is important to note that this technique is not expected to collect organically bound dissolved $\mathrm{Cr}\left(\mathrm{Cr}_{\mathrm{ORG}}\right)$, as this fraction is thought to be resistant to reduction and adsorption (Nakayama et al., 1981; Abu-Saba and Flegal, 1995). By contrast, previously published analyses of $\delta^{53} \mathrm{Cr}$ in river waters have been obtained from samples that were pre-concentrated by evaporation; a technique considered to capture $\mathrm{Cr}_{\mathrm{T}+\mathrm{ORG}}$ (Frei et al., 2014; Paulukat et al., 2015; D'Arcy et al., 2016). Nevertheless, a wide range of organic complexes with different binding strengths are present in the Beaulieu River (Hopwood et al., 2015), and our Fe co-precipitation method may capture weakly complexed $\mathrm{Cr}_{\mathrm{ORG}}$, thus $\mathrm{Cr}_{\mathrm{T}}$ values reported in this study are considered to be operationally defined. Filtered aliquots of two samples (B1 and B2) were analysed after UV irradiation for $\sim 3$ hours in LDPE bottles using a UV box containing $4 \times$ G20T10 lamps, in an attempt to oxidise any $\mathrm{Cr}_{\mathrm{ORg}}$ and assess the potential contribution of this fraction to the total dissolved $\mathrm{Cr}$ pool.

\subsection{Determination of $\mathrm{Cr}$ speciation in river and estuarine waters}

Dissolved $\mathrm{Cr}(\mathrm{III})$ concentrations were measured using a modified version of the Fe coprecipitation technique, wherein $\mathrm{Fe}(\mathrm{III})$ hydroxide was used in place of $\mathrm{Fe}(\mathrm{II})$ hydroxide to collect $\mathrm{Cr}(\mathrm{III})$ only. $\mathrm{Cr}(\mathrm{III})$ is strongly adsorbed to $\mathrm{Fe}(\mathrm{III})$ hydroxide, whereas $\mathrm{Cr}(\mathrm{VI})$ is not,

184 allowing effective separation of the two species (Shigematsu et al., 1977; Cranston and Murray, 1978; Dolamore-Frank, 1984; Jeandel and Minster, 1984). As for $\mathrm{Cr}_{\mathrm{T}}, \mathrm{Cr}(\mathrm{III})$ values 
filtered, spiked and treated with the Fe(III) hydroxide precipitate $(3 \mathrm{~mL})$ either in a class 100 clean laboratory at NOCS or on board the R.V. Bill Conway. The Fe(III) solution was prepared in the same manner as the Fe(II) solution described in Section 3.2, except it was allowed to oxidise for 1 week with occasional shaking. As the proportions of $\operatorname{Cr}(\mathrm{III})$ and $\mathrm{Cr}(\mathrm{VI})$ in natural water samples may change rapidly after sample collection (Kingston et al., 1998), coprecipitation was done within 4 hours of sample collection. Blank solutions of Milli-Q water were processed alongside the samples.

The ${ }^{50} \mathrm{Cr}+{ }^{54} \mathrm{Cr}$ double spike was replaced with a ${ }^{53} \mathrm{Cr}$ (III) single spike for $\mathrm{Cr}(\mathrm{III})$ analysis and isotope dilution calculations were made using the ${ }^{52} \mathrm{Cr} /{ }^{53} \mathrm{Cr}$ ratio. The lowest analytical error occurs when the ${ }^{52} \mathrm{Cr} /{ }^{53} \mathrm{Cr}$ ratio is 0.1 - 3.5 (Bedson, 2007); all samples had ratios of of 0.1 1.1. Despite the lack of isobaric interferences on ${ }^{52} \mathrm{Cr}$ and ${ }^{53} \mathrm{Cr}$, large quantities of residual $\mathrm{Fe}$ and salts will interfere with ICP-MS analysis so an ion exchange procedure similar to that described above was used to purify the $\mathrm{Cr}$ fraction. ${ }^{52} \mathrm{Cr} /{ }^{53} \mathrm{Cr}$ ratios were then measured on an Element 2 ICP-MS. The accuracy of this procedure was tested by processing $\mathrm{Cr}$ (III) standards (NBS979) and mixed $\mathrm{Cr}(\mathrm{III})+\mathrm{Cr}(\mathrm{VI})$ standards (NBS979 and potassium chromate, Fluka TraceCERT®) in the same way as samples. $\operatorname{Cr}(\mathrm{VI})$ concentrations were subsequently calculated by subtracting $\mathrm{Cr}(\mathrm{III})$ from $\mathrm{Cr}_{\mathrm{T}}$.

\subsection{Analysis of dissolved iron concentrations}

Total dissolved iron concentrations in the $<0.45 \mu \mathrm{m}$ fraction were measured using the ferrozine method (Stookey, 1970). Approximately $5 \mathrm{~mL}$ of each sample was filtered through pre-cleaned $0.45 \mu \mathrm{m}$ syringe filters (Millipore Millex) within 4 hours of collection. $3 \mathrm{~mL}$ aliquots of the filtered water were immediately pipetted into vials pre-loaded with $0.2 \mathrm{~mL}$ of $5 \mathrm{mM}$ ferrozine and $0.2 \mathrm{~mL}$ of $10 \mathrm{mM}$ ascorbic acid. A series of Fe standards $(0-50 \mu \mathrm{M}$, made with ammonium $\mathrm{Fe}(\mathrm{II})$ sulphate) were treated in the same way. Under these conditions all $\mathrm{Fe}(\mathrm{Fe}(\mathrm{II})+\mathrm{Fe}(\mathrm{III}))$ is converted to $\mathrm{Fe}(\mathrm{II})$ that reacts to form a purple complex with ferrozine. The method collects inorganic $\mathrm{Fe}$ as well as organically complexed $\mathrm{Fe}$, except for the most strongly bound $\mathrm{Fe}$ complexes (Hopwood et al., 2014). Fe concentrations were determined using a Unicom 8625 
215 UV/Visible spectrometer set to measure absorbance at $562 \mathrm{~nm}$. A $4 \mathrm{~cm}$ cell was used to 216 maximise sensitivity and the detection limit was $0.13 \mu \mathrm{M}$.

\subsection{Processing of push cores and sampling of pore waters}

218 Profiles of dissolved oxygen were measured for two of the four push cores using an optical oxygen meter (Pyroscience FirestingO2 with OX50 needle-type sensor) mounted on a micromanipulator (Pyroscience MU1). The uppermost $5 \mathrm{~cm}$ of sediment from each core was then centrifuged to extract the pore water. Pore waters were combined and centrifuged once more; co-precipitation with Fe was not necessary. The pore waters were then vacuum filtered through pre-cleaned $0.45 \mu \mathrm{m}$ membrane filters (Whatman Polycarbonate). Organic material was oxidised by addition of $0.2 \mathrm{~mL} \mathrm{H}_{2} \mathrm{O}_{2}$ and refluxing in $1 \mathrm{~mL}$ of aqua regia at $130^{\circ} \mathrm{C}$ for $\sim 24$ hours. Any precipitate was digested by refluxing in $0.5 \mathrm{~mL}$ of hydrogen fluoride at $170^{\circ} \mathrm{C}$ for 4 days. The samples were then dissolved in $3 \mathrm{~mL}$ of $7 \mathrm{M} \mathrm{HCl}$ and dried before being passed through the ion chromatography procedure. The total procedural blank was $\sim 3 \mathrm{ng}$, almost entirely contributed by the filter $(2.4 \pm 0.8 \mathrm{ng}, \mathrm{n}=3)$. This is less than $1 \%$ of the $\mathrm{Cr}$ processed and is therefore considered negligible.

\section{Results}

\subsection{Method validation}

232 It is essential that equilibration between natural $\mathrm{Cr}$ in the sample and $\mathrm{Cr}$ in the spike is achieved in order to produce accurate data, because the yield of $\mathrm{Cr}$ is $<100 \%$ ( $9-60 \%$ in samples with $S \leq 10$, and $60-85 \%$ in samples with $S \geq 10$ ). Equilibration is effective in seawater samples (Jeandel and Minster, 1984; Bonnand et al., 2013; Scheiderich et al., 2015; Goring-Harford et al., 2018), but to verify that this was also the case for low salinity samples, we tested an archived Beaulieu river water sample $(S=0)$ that had not been acidified for $\mathrm{Cr}_{\mathrm{T}}$, $\mathrm{Cr}(\mathrm{III})$ and $\mathrm{Cr}_{\mathrm{T}+\mathrm{ORG}}$ using the ${ }^{53} \mathrm{Cr}$ spike, yielding concentrations of $0.63 \mathrm{nmol} \mathrm{kg}{ }^{-1}, 0.37 \mathrm{nmol}$ $\mathrm{kg}^{-1}$ and $0.73 \mathrm{nmol} \mathrm{kg}{ }^{-1}$ respectively. To obtain an independent $\mathrm{Cr}_{\mathrm{T}+\mathrm{ORG}}$ value, two more aliquots were simply dried down and treated with $\mathrm{H}_{2} \mathrm{O}_{2}$ to eliminate organic matter before analysis on the Element 2 . The $\mathrm{Cr}_{\mathrm{T}+\mathrm{ORG}}$ values of these samples $\left(0.71 \pm 0.09 \mathrm{nmol} \mathrm{kg}^{-1} 2 \mathrm{SD}\right.$, 
$242 \mathrm{n}=2$ ) were within error of the spiked and co-precipitated sample. Thus, this investigation

243 demonstrates that: (i) spike equilibration is effective in low salinity waters containing a mixture 244 of $\mathrm{Cr}(\mathrm{III})$ and $\mathrm{Cr}(\mathrm{VI})$; (ii) $\mathrm{Cr}_{\mathrm{ORG}}$ is effectively released by UV irradiation; and (iii) all $\mathrm{Cr}$ species 245 have been determined by our analyses. Apart from its atomic mass, the ${ }^{50+54} \mathrm{Cr}$ spike is 246 identical to the ${ }^{53} \mathrm{Cr}$ spike, so it is reasonable to assume that spike equilibration was also 247 effective for $\mathrm{Cr}_{\mathrm{T}}$ and $\delta^{53} \mathrm{Cr}_{\mathrm{T}}$ analyses.

248 For speciation analyses, the average total procedural blank for the samples that were partly processed on board the R.V. Bill Conway was $0.08 \pm 0.02 \mathrm{nmol}(2 \mathrm{SD}, \mathrm{n}=2)$. This is within error 250 of our long term total procedural blank for samples processed in the clean laboratory $(0.09 \pm$ $2510.06 \mathrm{nmol} 2 \mathrm{SD} ; \mathrm{n}=13)$, implying that the samples were not compromised by handling outside of the clean laboratory. Several authors have shown that Fe(III) co-precipitation is an effective technique for measuring $\mathrm{Cr}(\mathrm{III})$ in natural waters, with or without employing an isotopic spike (Shigematsu et al., 1977; Cranston and Murray, 1978; Dolamore-Frank, 1984; Jeandel and Minster, 1984). To check that the method is capable of producing accurate $\mathrm{Cr}(\mathrm{III})$ concentrations with our ${ }^{53} \mathrm{Cr}$ spike, $\mathrm{Cr}(\mathrm{III})$ and mixed $\mathrm{Cr}(\mathrm{III})+\mathrm{Cr}(\mathrm{VI})$ standards in Milli-Q water were tested (Table 2). The $\mathrm{Cr}$ (III) standards gave values within $\pm 4 \%$ of the expected value, demonstrating that little $\mathrm{Cr}(\mathrm{III})$ was lost to container walls before sample-spike equilibration occurred. Mixed $\mathrm{Cr}(\mathrm{III})+\mathrm{Cr}(\mathrm{VI})$ standards had a slightly higher uncertainty of $\pm 10 \%$ (Table 1 ). The higher uncertainty of the mixed standards may reflect speciation changes prior to addition of the Fe precipitate, as this was not done until $\sim 24$ hours after spiking. In an effort to circumvent this issue, the Fe precipitate was added to river water and estuary samples within 4 hours of sample collection; nevertheless, the uncertainty of $\mathrm{Cr}(\mathrm{III}), \mathrm{Cr}(\mathrm{VI})$ and $\mathrm{Cr}_{\mathrm{T}}$ measurements are conservatively reported in this study as $\pm 10 \%$. In support of this, sample B13 was processed twice and yielded an average $\mathrm{Cr}(\mathrm{III})$ concentration of $0.25 \mathrm{nmol} \mathrm{kg}^{-1} \pm 7 \%$.

\section{2. $\mathrm{Cr}$ and $\delta^{53} \mathrm{Cr}_{\mathrm{T}}$ variation in estuarine waters}

267 The range of $\mathrm{Cr}_{\mathrm{T}}$ values for samples collected in March 2016 (1.64 to $1.89 \mathrm{nmol} \mathrm{kg}{ }^{-1}$; Table 2) was similar to that measured previously for this location $\left(1.64\right.$ to $5.05 \mathrm{nmol} \mathrm{kg}{ }^{-1}$; Bonnand et al. 

$\mathrm{nmol} \mathrm{kg}{ }^{-1}$ ). On both sampling dates $\mathrm{Cr}_{\mathrm{T}}$ decreased slightly with salinity. A negative correlation was observed between $\mathrm{Cr}(\mathrm{III})$ and salinity (Figure $3 \mathrm{C} ; \mathrm{R}^{2}=0.95, \mathrm{p}<10^{-7}$ for March, $\mathrm{R}^{2}=0.57$, $p<0.1$ for October), whereas $\mathrm{Cr}(\mathrm{VI})$ showed a positive correlation (Figure 3D; $\mathrm{R}^{2}=0.87, p<$ $10^{-5}$ for March, $\mathrm{R}^{2}=0.24, \mathrm{p}<0.4$ for October). Approximately $15 \%$ of $\mathrm{Cr}_{\mathrm{T}}$ was found to be present as $\mathrm{Cr}(\mathrm{III})$ in high salinity waters $(\mathrm{S}=>29)$, compared with up to $55 \%$ in low salinity waters $(S=<5)$. The $\delta^{53} \mathrm{Cr}_{\mathrm{T}}$ values $(-0.59$ to $1.68 \%)$ increased linearly with increasing salinity (Figure 3E; $\mathrm{R}^{2}=0.98, \mathrm{p}<10^{-10}$ for March, $\mathrm{R}^{2}=0.84, \mathrm{p}<0.02$ for October). Assuming that the relationship between salinity and $\delta^{53} \mathrm{Cr}_{\mathrm{T}}$ is linear, even at very low salinity (see Section 5.1 ), then the extrapolated $\delta^{53} \mathrm{Cr}_{\mathrm{T}}$ value of the river endmember at $S=0$ was the same in March $\left(\delta^{53} \mathrm{Cr}_{\mathrm{T} \text {-Calculated }}=-0.43 \pm 0.06 \%\right)$ and October $\left(\delta^{53} \mathrm{Cr}_{\mathrm{T} \text {-CALCUlATEd }}=-0.34 \pm 0.13 \%\right.$ ).

\section{3. $\mathrm{Cr}$ associated with organic material}

Tests performed using the ${ }^{53} \mathrm{Cr}$ single spike method demonstrated that UV irradiation did not contribute any significant $\mathrm{Cr}$ to the total procedural blank, as the average UV irradiated blank $(0.06 \pm 0.03 \mathrm{nmol}, \mathrm{n}=3)$ was within error of the long term procedural blank $(0.09 \pm 0.06 \mathrm{nmol}$; $n=13)$.

Water samples B1 and B2 irradiated with UV light had higher dissolved Cr concentrations $\left(\mathrm{Cr}_{\mathrm{T}+\mathrm{ORG}}\right)$ compared to non-irradiated aliquots, indicating that at least $18 \%$ of the $\mathrm{Cr}$ in low to mid salinity waters was organically bound (Table 3). The UV-irradiated samples also had lower $\delta^{53} \mathrm{Cr}_{\mathrm{T}+\mathrm{ORG}}$ compared to $\delta^{53} \mathrm{Cr}_{\mathrm{T}}$ in non-irradiated samples, which implies that the $\mathrm{Cr}_{\mathrm{ORG}}$ fraction has a lower $\delta^{53} \mathrm{Cr}$ composition than the $\mathrm{Cr}_{\mathrm{T}}$ fraction. The $\delta^{53} \mathrm{Cr}$ value of $\mathrm{Cr}_{\mathrm{ORG}}$ is given by:

$$
\delta^{53} \mathrm{Cr}_{\mathrm{ORG}}=\frac{\left(\delta^{53} \mathrm{Cr}_{\mathrm{T}+\mathrm{ORG}}-\left(\mathrm{F}_{\mathrm{T}} \times \delta^{53} \mathrm{Cr}_{\mathrm{T}}\right)\right)}{\mathrm{F}_{\mathrm{ORG}}}
$$

291 Where $\mathrm{F}_{\mathrm{T}}=\mathrm{Cr}_{\mathrm{T}} / \mathrm{Cr}_{\mathrm{T}+\mathrm{ORG}}$ and $\mathrm{F}_{\mathrm{ORG}}=\mathrm{Cr}_{\mathrm{ORG}} / \mathrm{Cr}_{\mathrm{T}+\mathrm{ORG}} . \mathrm{B} 1$ and $\mathrm{B} 2$ yield $\delta^{53} \mathrm{Cr}_{\mathrm{ORG}}$ values of 292 $0.75 \%$ and $-0.11 \%$, respectively (Table 3 ). 
294 The sediment core-top waters contained $230-260 \mu \mathrm{M}$ of dissolved $\mathrm{O}_{2}$, and the $\mathrm{pH}$ was 6.9 at approximately $1 \mathrm{~cm}$ depth below the river bed (measured in one core only). Oxygen profiles (Figure 4) revealed a shallow oxygen penetration depth of $2.9 \pm 1.7 \mathrm{~mm}(2 \mathrm{SD})$ below the sediment-water interface. $\mathrm{Cr}_{\mathrm{T}}$ concentrations of pore waters from the two cores were 100 and $120 \mathrm{nmol} \mathrm{kg}{ }^{-1}$ and $\delta^{53} \mathrm{Cr}_{\mathrm{T}+\mathrm{ORG}}$ values were $0.06 \pm 0.05 \%$ and $0.13 \pm 0.05 \%$ respectively. These analyses included any $\mathrm{Cr}_{\mathrm{ORG}}$ in the pore waters as the Fe co-precipitation method was not used.

\section{Discussion}

\subsection{Behaviour of $\mathrm{Cr}$ and $\mathrm{Cr}$ isotopes during estuarine mixing}

303 Concentrations of $\mathrm{Cr}_{\mathrm{T}}$ in samples collected in October were significantly lower than in March, and compared to previous measurements (Dolamore-Frank, 1984). Dilution of surface water $\mathrm{Cr}$ may have played a part as there was more rainfall $(8.8 \mathrm{~mm})$ in October, however this cannot explain a reduction of $-50 \%$ in $\mathrm{Cr}_{\mathrm{T}}$. Another explanation is that a greater proportion of dissolved $\mathrm{Cr}$ (III) was contained in the organic fraction (which is not captured by our Fe coprecipitation method) due to the release of dissolved organic material in the autumn following the decomposition of deciduous tree leaves; this would have affected even the high salinity sample $(B 20, S=29.6)$ because it was taken from a well vegetated part of the river (Figure 2). Organic molecules from leaf litter leachates have been shown to strongly bind copper in the early stages of decomposition because microbes transform or consume the most effective organic ligands (proteins and polyphenol-like compounds) over time (Cuss and Gueguen, 2012). It is possible that a similar situation applies to Cr. In support of this, large amounts of foam were observed on the river surface in October, suggesting that concentrations of organic surfactants were high.

317 Figure 3A provides evidence for the removal of dissolved iron at low salinities in the Beaulieu

318 Estuary as observed in previous studies (Holliday and Liss, 1976; Fang, 1995), which is 319 thought to reflect the incorporation of Fe into flocculated organic particles (Sholkovitz et al., 
1978; Moore et al., 1979; Hopwood et al., 2014). However, no relationship was observed

321 between $\mathrm{Cr}_{\mathrm{T}}$ and dFe concentrations at low salinities $\left(\mathrm{R}^{2}=0.01\right.$ for October), suggesting that

322 inorganic $\mathrm{Cr}$ species were unaffected by the flocculation of organic material during the

323 transition from river to estuary.

324 Concentrations of $\mathrm{Cr}(\mathrm{VI}), \mathrm{Cr}(\mathrm{III})$ and $\delta^{53} \mathrm{Cr}_{\mathrm{T}}$ exhibited linear relationships with salinity on both sampling dates, whilst $\mathrm{Cr}_{\mathrm{T}}$ showed little variation with salinity because the river and seawater endmembers had similar $\mathrm{Cr}_{\mathrm{T}}$ concentrations (Figure 3B-E). Re-release of $\mathrm{Cr}$ from particulate material at high salinities has previously been observed in both the Beaulieu estuary 328 (Dolamore-Frank, 1984) and the Connecticut estuary (Sun et al., 2019), but there was no increase in $\mathrm{Cr}_{\mathrm{T}}$ that would suggest a similar mechanism in this case. Furthermore, the relationship between $\delta^{53} \mathrm{Cr}_{\mathrm{T}}$ and salinity was much stronger $\left(\mathrm{R}^{2}=0.98\right.$ and 0.84 for March and October respectively; Figure 3E) than that between $\delta^{53} \mathrm{Cr}_{\mathrm{T}}$ and $\mathrm{Cr}_{\mathrm{T}}\left(\mathrm{R}^{2}=0.24\right.$ and 0.00 for March and October respectively; Figure 3F), strongly suggesting that salinity, rather than reduction and removal of isotopically light $\mathrm{Cr}(\mathrm{III})$, exerts the main control on $\delta^{53} \mathrm{Cr}_{\mathrm{T}}$. The distributions of $\mathrm{Cr}(\mathrm{VI}), \mathrm{Cr}(\mathrm{III})$ and $\delta^{53} \mathrm{Cr}_{\mathrm{T}}$ in the Beaulieu estuary are therefore thought to be principally controlled by simple mixing between a high $\mathrm{Cr}(\mathrm{III}) / \mathrm{low} \mathrm{Cr}(\mathrm{VI})$, low $\delta^{53} \mathrm{Cr}_{\mathrm{T}}$ river water endmember and a low $\mathrm{Cr}(\mathrm{III}) / \mathrm{high} \mathrm{Cr}(\mathrm{VI})$, high $\delta^{53} \mathrm{Cr}_{\mathrm{T}}$ seawater endmember. This is supported by our mixing model (Figure 5; see Sections 5.2 and 5.3), where river and seawater endmember values for $\mathrm{Cr}(\mathrm{III}), \mathrm{Cr}(\mathrm{VI})$ and $\delta^{53} \mathrm{Cr}_{\mathrm{T}}$ for March have been calculated by linear extrapolation, and intermediate values calculated by adding the proportions contributed by the endmembers; there is good agreement between model and measured values. These findings contrast with those from the Connecticut estuary, where $\mathrm{Cr}$ removal onto suspended

342 particulate material and into sediments at low to moderate salinities appeared to be associated with $\mathrm{Cr}$ isotope fractionation (Sun et al., 2019).

344 It is possible that removal of $\mathrm{Cr}(\mathrm{III})$ and/or $\mathrm{Cr}(\mathrm{VI})$ occurs at very low salinities $(<0.5)$, because sample B1 (which was taken from further upstream than the other samples), had a much higher $\mathrm{Cr}_{\mathrm{T}}$ concentration $\left(5.05 \mathrm{nmol} \mathrm{kg}^{-1}\right)$ than the other samples. Reduction of $\mathrm{Cr}(\mathrm{VI})$ and 
subsequent removal of the $\mathrm{Cr}(\mathrm{III})$ that forms would drive the $\delta^{53} \mathrm{Cr}_{\mathrm{T}}$ composition of the

348 remaining dissolved $\mathrm{Cr}$ to a higher value because the fractionation factors for $\mathrm{Cr}(\mathrm{VI})$ reduction

349 by $\mathrm{Fe}(\mathrm{II})$ or DOC, the most abundant reductants in the Beaulieu River system, are large $\left(\Delta_{\mathrm{cr}(\mathrm{VI}) \text { - }}\right.$ $350 \mathrm{Cr}(\mathrm{III})=3.6$ to $4.2 \%$ and 3.1\% respectively; Døssing et al. 2011; Kitchen et al. 2012). Figure 5A 351 models the $\delta^{53} \mathrm{Cr}_{\mathrm{T}}$ value of remaining dissolved $\mathrm{Cr}$ in the Beaulieu estuary for March, assuming that all of the $\mathrm{Cr}(\mathrm{III})$ in sample $\mathrm{B} 1\left(3.21 \mathrm{nmol} \mathrm{kg}^{-1}, 64 \%\right.$ of the $\left.\mathrm{Cr}_{\mathrm{T}}\right)$ was produced by reduction of $\mathrm{Cr}(\mathrm{VI})$, and that this $\mathrm{Cr}(\mathrm{III})$ was subsequently removed at $S=<0.5$, followed by conservative mixing at higher salinities. It is clear that this would result in much higher ${ }^{53} \mathrm{Cr}_{\mathrm{T}}$ values than those observed in the estuary, which instead fall along a conservative mixing line with a river water endmember $\delta^{53} \mathrm{Cr}_{\text {T-CALCULATED }}$ value of $-0.39 \%$ o (see Section 5.2 ). Therefore, if $\mathrm{Cr}$ removal does occur, it must be associated with no, or minimal, isotopic fractionation.

\subsection{Controls on the $\mathrm{Cr}$ concentration and $\mathrm{Cr}$ isotopic composition of the river} water endmember

The variation in $\mathrm{Cr}_{\mathrm{T}}$ and $\delta^{53} \mathrm{Cr}_{\mathrm{T}}$ values is higher in the lower salinity samples that were collected from upstream of the sluice gate ( $S=\leq 14.5$; Figure 3$)$. In particular, samples B1 and B17 have high $\delta^{53} \mathrm{Cr}_{\mathrm{T}}$, high $\mathrm{Cr}_{\mathrm{T}}$ and a low proportion of $\mathrm{Cr}(\mathrm{III})$ relative to samples of similar salinity that may be indicative of input of $\mathrm{Cr}$ from a different source. Nevertheless, overall there is a linear relationship between $\delta^{53} \mathrm{Cr}_{\mathrm{T}}$ and salinity, so the average $\delta^{53} \mathrm{Cr}_{\mathrm{T}}$ value of the river water endmember can be estimated by extrapolating the regression line to $S=0$. The estimated $\delta^{53} \mathrm{Cr}_{\mathrm{T}}$ value of the river water endmember, based on both the March and October data, is $-0.39 \pm 0.08 \%$, lower than the range determined for most other rivers to date (Figure 1). It is also lower than the $\delta^{53} \mathrm{Cr}$ value of crustal rocks $(-0.12 \pm 0.10 \%$; Schoenberg et al. 2008), and the $\delta^{53} \mathrm{Cr}_{\mathrm{T}+\mathrm{ORG}}$ values of pore waters in Beaulieu River bed sediments (0.06 to $0.13 \%$ ). Although $\mathrm{Cr}$ isotope fractionation during oxidative weathering is poorly characterised,

371 it is expected to produce aqueous $\mathrm{Cr}(\mathrm{VI})$ that has a higher $\delta^{53} \mathrm{Cr}$ value than the crustal value 372 (e.g. Frei et al. 2014; D'Arcy et al. 2016), thus oxidative weathering cannot be the principal control on the $\delta^{53} \mathrm{Cr}_{\mathrm{T}}$ value of the Beaulieu River. 
374 Chromium can also be released into solution via dissolution of sedimentary $\mathrm{Fe}-\mathrm{Cr}$ 375 (oxy)hydroxides under anoxic conditions (Rigaud et al., 2013). The oxic-anoxic boundary is 376 located close to the sediment-water interface in the Beaulieu River (Figure 4), thus given the 377 high concentration of dissolved $\mathrm{Cr}_{\mathrm{T}+\mathrm{ORG}}$ in the sediment pore waters $\left(100-120 \mathrm{nmol} \mathrm{kg}^{-1}\right)$, 378 diffusion of dissolved $\mathrm{Cr}$ (III) derived from the dissolution of $\mathrm{Fe}-\mathrm{Cr}$ (oxy)hydroxides could be an 379 important source of $\mathrm{Cr}$ into the Beaulieu river. Chromium contained in (oxy)hydroxides is expected to be enriched in lighter Cr isotopes (Døssing et al., 2011; Kitchen et al., 2012), so

381 this mechanism may also account for the low $\delta^{53} \mathrm{Cr}_{\mathrm{T}}$ values in the Beaulieu river endmember.

382 Analyses of sediment pore waters from the Beaulieu do not support this scenario, however, as their $\delta^{53} \mathrm{Cr}_{\mathrm{T}+\mathrm{ORG}}$ values $(0.06 \%$ and $0.13 \%$ ) were higher than that of the river water endmember $\left(\delta^{53} \mathrm{Cr}_{\mathrm{T} \text {-CALCULATED }}=-0.39 \%\right.$; measured values as low as $\left.-0.59 \%\right)$. Instead, we suggest that the $\delta^{53} \mathrm{Cr}_{\mathrm{T}}$ value of Beaulieu River water is primarily controlled by the presence of organic ligands (Figure 6). Mobile organic $\mathrm{Cr}$ (III) species are likely to form in the soil solution (Icopini and Long, 2002; Beck et al., 2008; Rigaud et al., 2013), and may be released into river waters. Formation of these organic $\mathrm{Cr}(\mathrm{III})$ complexes can occur via inorganic or biological reduction of $\mathrm{Cr}(\mathrm{VI})$, which may be derived from oxidation of $\mathrm{Cr}(\mathrm{III})$ in the uppermost oxic sediments, or from $\mathrm{Cr}(\mathrm{VI})$ that has formed via the diffusion and oxidation of dissolved $\mathrm{Cr}(\mathrm{III})$ originating from the underlying anoxic zone. Reduction of $\mathrm{Cr}(\mathrm{VI})$ by both mechanisms is associated with large isotopic fractionation factors $\left(\Delta_{\operatorname{cr}(\mathrm{VI})-\operatorname{Cr}(\mathrm{III})}=1.8-4.5 \%\right.$ for various bacteria and 3.1\% for organic molecules; Sikora et al. 2008; Han et al. 2012; Kitchen et al. 2012; Basu et al. 2014). Thus, organic $\mathrm{Cr}(\mathrm{III})$ complexes produced in this way are likely to have a low $\delta^{53} \mathrm{Cr}$ value, consistent with our findings for $\delta^{53} \mathrm{Cr}_{\mathrm{ORG}}$ in the Beaulieu (-0.8 to $-0.1 \%$; Table 3 ). Dissociation of these low $\delta^{53} \mathrm{Cr}(\mathrm{III})$ bearing complexes by photochemical reactions (Kieber and Helz, 1992) would also explain why $\delta^{53} \mathrm{Cr}_{\mathrm{T}}$ values were low and the proportion of dissolved $\mathrm{Cr}$ (III) was high in low salinity waters, and particularly as we sampled very shallow waters on clear, sunny days. In support of this hypothesis, it is notable that the $\delta^{53} \mathrm{Cr}_{\mathrm{T}+\mathrm{ORG}}$ value of the

400 UV irradiated sample B1 (0.06\%) was very similar to that of the pore waters $(0.06-0.13 \%)$ that 401 were sampled in very close proximity; it appears that the river water directly reflects the pore 
water $\mathrm{Cr}$ source when $\mathrm{Cr}_{\mathrm{ORG}}$ is taken into account. The changing proportion of $\mathrm{Cr}$ released

403 into solution via this process versus Cr released due to oxidative weathering may also explain 404 the higher scatter in the data at low salinities.

405

406

407

408

409

410

411

412

413

414

415

416

417

418

419

420

421

422

423

424

425

426

427

428

\subsection{Controls on the $\mathrm{Cr}$ concentration and $\mathrm{Cr}$ isotopic composition of the seawater} endmember

The estimated $\delta^{53} \mathrm{Cr}_{\mathrm{T}}$ value of the coastal seawater endmember at $S=35(1.6 \pm 0.4 \%$; calculated using March and October data) is similar to those previously measured in shelf waters (typically 1.3 to $1.5 \%$, $S=30$ to 34 ; Bonnand et al. 2013; Scheiderich et al. 2015; Goring-Harford et al. 2018), but higher than the values typically measured in oxic deep water masses (1.0 to 1.2\%; Bonnand et al. 2013; Scheiderich et al. 2015; Goring-Harford et al. 2018). This likely reflects internal cycling of $\mathrm{Cr}$ within coastal and shelf waters, e.g. the reduction of $\mathrm{Cr}(\mathrm{VI})$ to $\mathrm{Cr}(\mathrm{III})$ in surface waters followed by removal onto biogenic particles, and the release of $\mathrm{Cr}$ from sedimentary sources (Scheiderich et al., 2015; Goring-Harford et al., 2018), Because the volume of the Beaulieu River is far smaller than that of Southampton Water and its $\mathrm{Cr}_{\mathrm{T}}$ is low, the low $\delta^{53} \mathrm{Cr}_{\mathrm{T}}$ of the Beaulieu River does not have a significant impact Southampton Water $\delta^{53} \mathrm{Cr}_{\mathrm{T}}$ values. In other estuarine systems, however, high salinity shelf waters (which typically have similar $\mathrm{Cr}$ concentrations to Southampton Water, $\sim 2 \mathrm{nM}$; Scheiderich et al. 2015; Goring-Harford et al. 2018) may be significantly impacted by riverine $\delta^{53} \mathrm{Cr}_{\mathrm{T}}$ if there is a larger riverine $\mathrm{Cr}$ input. Figure 7 shows how $\delta^{53} \mathrm{Cr}_{\mathrm{T}}$ values in high salinity waters would be modified by a river with similar $\delta^{53} \mathrm{Cr}_{\mathrm{T}}$ to the Beaulieu and a higher $\mathrm{Cr}_{\mathrm{T}}$ of 15nM (similar to, for example, the Humber River; Comber and Gardner 2003). In this situation, the riverine input would still be significantly impacting $\delta^{53} \mathrm{Cr}_{\mathrm{T}}$ at $S=34(1.18 \%$ ), causing it to be over $0.4 \%$ lower than the seawater endmember $\left(S=35, \delta^{53} \mathrm{Cr}_{\mathrm{T}}=1.60 \%\right.$ ), whereas for a river like the Beaulieu (with much lower $\mathrm{Cr}_{\mathrm{T}}$ ), the difference is $<0.1 \%$. Thus, rivers with high $\mathrm{Cr}_{\mathrm{T}}$ may influence the $\delta^{53} \mathrm{Cr}$ value of high salinity estuarine waters, and possibly even the adjacent continental shelf waters if the river and seawater endmembers also have very different $\delta^{53} \mathrm{Cr}$ values. 
430 Whilst our data provide no insight as to the behaviour of organically bound $\mathrm{Cr}$ in estuaries, 431 significant quantities of $\mathrm{Cr}_{\mathrm{ORG}}$ are unlikely to be transferred to the open ocean because DOC

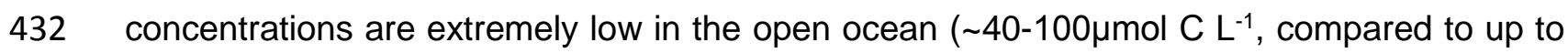
$433 \sim 5 \mathrm{mmol} \mathrm{C} \mathrm{L} \mathrm{L}^{-1}$ in the Beaulieu River; e.g. Miller and Zepp 1995; Hansell and Carlson 1998). 434 Furthermore, organically bound $\mathrm{Cr}$ in the Beaulieu River is $<20 \%$ of the total $\mathrm{Cr}$, even though 435 it has far higher DOC concentrations than most other rivers (Moore et al., 1979). Thus, Cr is 436 most likely to be transferred to the ocean in its inorganic forms, with the composition of the 437 dissolved $\mathrm{Cr}(\mathrm{III})$ and $\mathrm{Cr}(\mathrm{VI})$ species controlling the 'baseline' $\delta^{53} \mathrm{Cr}$ value of seawater on a 438 global scale (though modifications will occur in the ocean itself; Scheiderich et al. 2015; 439 Goring-Harford et al. 2018; Bruggmann et al. 2019). Our study shows that inorganic forms of 440 dissolved $\mathrm{Cr}$ behave conservatively during estuarine mixing in the Beaulieu and that $\mathrm{Cr}(\mathrm{VI})$ is not reduced to $\mathrm{Cr}(\mathrm{III})$. If this were true for all estuaries, the global average riverine $\delta^{53} \mathrm{Cr}$ value

442 would be faithfully transferred to the ocean. However, our study also reveals that anoxic, rather 443 than oxidative, weathering processes are likely to be the principal source of $\mathrm{Cr}$ to the Beaulieu 444 River, and that the $\delta^{53} \mathrm{Cr}$ value of the river water endmember is controlled by complexation with organic ligands. The operation of fractionating processes beside oxidative weathering potentially complicates the interpretation of seawater $\delta^{53} \mathrm{Cr}$ values in terms of the level of

447 atmospheric oxygenation, although we note that on a global scale, the input of $\mathrm{Cr}$ from 448 oxidative weathering in mafic catchments is likely to be far more important source of $\mathrm{Cr}$ to the 449 oceans than from organic rich, non-mafic catchments (McClain and Maher, 2016).

450 Finally, in a scenario where riverine $\delta^{53} \mathrm{Cr}$ values are dissimilar to those of seawater, and 451 especially where the riverine $\mathrm{Cr}$ concentration is high, $\delta^{53} \mathrm{Cr}$ values of shelf waters may be 452 significantly influenced by input of riverine $\mathrm{Cr}$ (Figure 7). As a result, shelf sediments are likely 453 to be poor candidates for redox proxy studies, because $\delta^{53} \mathrm{Cr}$ values will reflect a mixture of 454 local and global scale processes. 


\section{Conclusions}

456 In contrast to most river systems that have relatively high $\delta^{53} \mathrm{Cr}$ values due to release of $\mathrm{Cr}(\mathrm{VI})$

457 by oxidative weathering processes, dissolved $\mathrm{Cr}$ in the Beaulieu River is characterised by low $458 \delta^{53} \mathrm{Cr}_{\mathrm{T}}$ values (-0.59 to $0.24 \%$ ). We suggest that in this DOC-rich river system, pore water $459 \mathrm{Cr}(\mathrm{VI})$ is partly back-reduced to $\mathrm{Cr}(\mathrm{III})$ by organic or Fe(II) reductants, and the formation of 460 organic complexes keeps the $\mathrm{Cr}(\mathrm{III})$ in solution. Our results also demonstrated that $\operatorname{Cr}(\mathrm{III})$, $461 \mathrm{Cr}(\mathrm{VI})$ and $\mathrm{Cr}$ isotopes behave conservatively in the estuarine mixing zone and, even in the 462 presence of high concentrations of $\mathrm{dFe}$ and $\mathrm{DOC}$, we found no evidence for reduction of $\mathrm{Cr}(\mathrm{VI})$ 463 to $\mathrm{Cr}(\mathrm{III})$.

464 Knowledge of the behaviour of $\mathrm{Cr}$ and $\mathrm{Cr}$ isotopes in rivers and during estuarine mixing is 465 essential for the interpretation of the $\mathrm{Cr}$ isotope redox proxy. We have shown that oxidative 466 weathering is not the only source of dissolved $\mathrm{Cr}$ in organic-rich river systems, and that input 467 of $\mathrm{Cr}$ from anoxic weathering processes contributes $\mathrm{Cr}$ with a distinctly lower $\delta^{53} \mathrm{Cr}$ value ( $4680.4 \%$ ). At the global scale, however, such organic-rich rivers are unlikely to be an important 469 source of dissolved $\mathrm{Cr}$ to the oceans. While inorganic riverine $\delta^{53} \mathrm{Cr}$ values appear to be 470 unmodified during estuarine mixing, the estimated $\delta^{53} \mathrm{Cr}$ value of the seawater endmember $471(1.6 \pm 0.4 \%)$ is higher than the range reported to date for most deep water masses (1.0-1.2\%o), 472 which supports existing evidence that cycling of $\mathrm{Cr}$ within coastal and shelf seas may modify 473 the $\delta^{53} \mathrm{Cr}$ value of seawater (Scheiderich et al., 2015; Goring-Harford et al., 2018). Internal 474 biogeochemical cycling of oceanic $\mathrm{Cr}$ therefore needs to be taken into consideration in the 475 interpretation of the seawater $\delta^{53} \mathrm{Cr}$ record preserved in authigenic marine sediments in terms 476 of oxidative weathering. We also show that even in estuaries where $\mathrm{Cr}$ behaves 477 conservatively, $\delta^{53} \mathrm{Cr}$ values of shelf waters can be modified by input of riverine $\mathrm{Cr}$. The 478 sedimentary record of seawater $\delta^{53} \mathrm{Cr}$ in these settings may therefore reflect local, rather than 479 global, processes. 


\section{Acknowledgements}

481 This work was partly supported by NERC grant NE/H006443/1. HJGH was supported by a $482 \mathrm{PhD}$ studentship funded by the Graduate School of the National Oceanography Centre 483 Southampton (NOCS), the University of Southampton and the NERC National Capability 484 programme. We thank Graham Blythe and Kevin Padley for assistance with fieldwork and 485 Andy Milton for technical support for the Element and Neptune mass spectrometers. 
Abu-Saba, K.E. and Flegal, A.R. (1995) Chromium in San Francisco Bay: superposition of geochemical processes causes complex spatial distributions of redox species. Mar. Chem. 49, 189-199.

Andronikov, A.V., Novak, M., Borodulina, G.S., Efremenko, N.A., Andronikova, I.E., Chesalina, G.L., Levichev, M.A., Subetto, D.A., Sebek, O. and Zobkova, M.V. (2019) One river, two streams: chemical and chromium isotopic features of the Neglinka River (Karelia, northwest Russia). Hydrological Sciences Journal.

Basu, A., Johnson, T.M. and Sanford, R.A. (2014) Cr isotope fractionation factors for $\mathrm{Cr}(\mathrm{VI})$ reduction by a metabolically diverse group of bacteria. Geochim. Cosmochim. Acta 142, 349-361.

Beck, M., Dellwig, O., Schnetger, B. and Brumsack, H.-J. (2008) Cycling of trace metals (Mn, Fe, Mo, U, V, Cr) in deep pore waters of intertidal flat sediments. Geochim. Cosmochim. Acta 72, 2822-2840.

Bedson, P. (2007) Guidelines for achieving high accuracy in isotope dilution mass spectrometry (IDMS). Royal Society of Chemistry, Cambridge, GBR.

Bonnand, P., James, R.H., Parkinson, I.J., Connelly, D.P. and Fairchild, I.J. (2013) The chromium isotopic composition of seawater and marine carbonates. Earth. Planet. Sci. Lett. 382, 10-20.

Bruggmann, S., Scholz, F., Klaebe, R.M., Canfield, D.E. and Frei, R. (2019) Chromium isotope cycling in the water column and sediments of the Peruvian continental margin. Geochim. Cosmochim. Acta 257, 224-242.

Buerge, I.J. and Hug, S.J. (1998) Influence of organic ligands on chromium(VI) reduction by iron(II). Environ. Sci. Technol. 32, 2092-2099.

Campbell, J.A. and Yeats, P.A. (1984) Dissolved Chromium in the St. Lawrence Estuary. Estuar. Coast. Shelf Sci. 19, 513-522.

Comber, S. and Gardner, M. (2003) Chromium redox speciation in natural waters. J. Environ. Monit. 5, 410-413.

Cranston, R.E. and Murray, J.W. (1978) The determination of chromium species in natural waters. Anal. Chim. Acta 99, 275-282.

Cranston, R.E. and Murray, J.W. (1980) Chromium species in the Columbia River and estuary. Limnol. Oceanogr. 25, 1104-1112. 
530 Crowe, S.A., Døssing, L.N., Beukes, N.J., Bau, M., Kruger, S.J., Frei, R. and Canfield,

531 D.E. (2013) Atmospheric oxygenation three billion years ago. Nature 501, 535-538.

532

533

534

535

536

537

538

539

540

541

542

543

544

545

546

547

548

549

550

551

552

553

554

555

556

557

558

559

560

561

562

563

564

565

566

567

568

569

Cuss, C. and Gueguen, C. (2012) Impacts of Microbial Activity on the Optical and Copper-Binding Properties of Leaf-Litter Leachate. Frontiers in Microbiology 3, 166.

D'Arcy, J., Babechuk, M.G., Døssing, L.N., Gaucher, C. and Frei, R. (2016) Processes controlling the chromium isotopic composition of river water: Constrains from basaltic river catchments. Geochim. Cosmochim. Acta 186, 296-315.

Dolamore-Frank, J.A. (1984) The analysis, occurrence and chemical speciation of zinc and chromium in natural waters. University of Southampton, UK.

Døssing, L.N., Dideriksen, K., Stipp, S.L.S. and Frei, R. (2011) Reduction of hexavalent chromium by ferrous iron: A process of chromium isotope fractionation and its relevance to natural environments. Chem. Geol. 285, 157-166.

Dyer, K.R. and Lasta King, H. (1975) The Residual Water Flow through the Solent, South England. Geophysical Journal International 42, 97-106.

Elderfield, H. (1970) Chromium speciation in seawater. Earth. Planet. Sci. Lett. 9, 1016.

Ellis, A.S., Johnson, T.M. and Bullen, T.D. (2002) Chromium isotopes and the fate of hexavalent chromium in the environment. Science 295, 2060-2062.

Fang, T.-H. (1995) Studies of the behaviour of trace metals during mixing in some estuaries of the Solent region. University of Southampton.

Frei, R., Gaucher, C., Poulton, S.W. and Canfield, D.E. (2009) Fluctuations in Precambrian atmospheric oxygenation recorded by chromium isotopes. Nature $\mathbf{4 6 1}$, 250-253.

Frei, R., Poiré, D. and Frei, K.M. (2014) Weathering on land and transport of chromium to the ocean in a subtropical region (Misiones, NW Argentina): A chromium stable isotope perspective. Chem. Geol. 381, 110-124.

Gaillardet, J., Viers, J. and Dupré, B. (2003) 5.09 - Trace elements in river waters, in: Holland, H.D., Turekian, K.K. (Eds.), Treatise on Geochemistry. Pergamon, Oxford, pp. 225-272. 
571 Gardner, M.J. and Ravenscroft, J.E. (1996) Determination of chromium(III) and total

572 chromium in marine waters. Fresenius J. Anal. Chem. 354, 602-605.

573

574

575

576

577

578

579

580

581

582

583

584

585

586

587

588

589

590

591

592

593

594

595

596

597

598

599

600

601

602

603

604

605

606

607

608

609

610

611
Gilkes, R.J. (1968) Clay Mineral Provinces in the Tertiary Sediments of the Hampshire Basin. Clay Minerals 7, 351-361.

Goring-Harford, H.J., Klar, J.K., Pearce, C.R., Connelly, D.P., Achterberg, E.P. and James, R.H. (2018) Behaviour of chromium isotopes in the eastern sub-tropical Atlantic Oxygen Minimum Zone. Geochim. Cosmochim. Acta 236, 41-59.

Han, R., Qin, L., Brown, S.T., Christensen, J.N. and Beller, H.R. (2012) Differential isotopic fractionation during $\mathrm{Cr}(\mathrm{VI})$ reduction by an aquifer-derived bacterium under aerobic versus denitrifying conditions. Appl. Environ. Microbiol. 78, 2462-2464.

Hansell, D.A. and Carlson, C.A. (1998) Deep-ocean gradients in the concentration of dissolved organic carbon. Nature 395, 263-266.

Holliday, L.M. and Liss, P.S. (1976) The behaviour of dissolved iron, manganese and zinc in the Beaulieu Estuary, S. England. Estuarine and Coastal Marine Science 4, 349-353.

Holmden, C., Jacobson, A.D., Sageman, B.B. and Hurtgen, M.T. (2016) Response of the $\mathrm{Cr}$ isotope proxy to Cretaceous Ocean Anoxic Event 2 in a pelagic carbonate succession from the Western Interior Seaway. Geochim. Cosmochim. Acta 186, 277295.

Hopwood, M.J., Statham, P.J. and Milani, A. (2014) Dissolved Fe(II) in a river-estuary system rich in dissolved organic matter. Estuar. Coast. Shelf Sci. 151, 1-9.

Hopwood, M.J., Statham, P.J., Skrabal, S.A. and Willey, J.D. (2015) Dissolved iron(II) ligands in river and estuarine water. Mar. Chem. 173, 173-182.

Icopini, G.A. and Long, D.T. (2002) Speciation of Aqueous Chromium by Use of SolidPhase Extractions in the Field. Environ. Sci. Technol. 36, 2994-2999.

Jeandel, C. and Minster, J.F. (1984) Isotope dilution measurement of inorganic chromium(III) and total chromium in seawater. Mar. Chem. 14, 347-364.

Jeandel, C. and Minster, J.F. (1987) Chromium behaviour in the ocean: Global versus regional processes. Global Biogeochem. Cycles 1, 131-154. 
612 Jonas, P.J.C. and Millward, G.E. (2010) Metals and nutrients in the Severn Estuary

613 and Bristol Channel: Contemporary inputs and distributions. Mar. Pollut. Bull. 61, 52-

61467.

615

616

617

618

619

620

621

622

623

624

625

626

627

628

629

630

631

632

633

634

635

636

637

638

639

640

641

642

643

644

645

646

647

648

649

650

651

652

653

654

Kaczynski, S.E. and Kieber, R.J. (1994) Hydrophobic C18 bound organic complexes of chromium and their potential impact on the geochemistry of chromium in natural waters. Environ. Sci. Technol. 28, 799-804.

Kieber, R.J. and Helz, G.R. (1992) Indirect photoreduction of aqueous chromium(VI). Environ. Sci. Technol. 26, 307-312.

Kingston, H.M., Huo, D., Lu, Y. and Chalk, S. (1998) Accuracy in species analysis: speciated isotope dilution mass spectrometry (SIDMS) exemplified by the evaluation of chromium species. Spectrochim. Acta, Part B 53, 299-309.

Kitchen, J.W., Johnson, T.M., Bullen, T.D., Zhu, J. and Raddatz, A. (2012) Chromium isotope fractionation factors for reduction of $\mathrm{Cr}(\mathrm{VI})$ by aqueous $\mathrm{Fe}(\mathrm{II})$ and organic molecules. Geochim. Cosmochim. Acta 89, 190-201.

Mayer, L.M. and Schick, L.L. (1981) Removal of hexavalent chromium from estuarine waters by model substrates and natural sediments. Environ. Sci. Technol. 15, 14821484.

McClain, C.N. and Maher, K. (2016) Chromium fluxes and speciation in ultramafic catchments and global rivers. Chem. Geol. 426, 135-157.

Miller, W.L. and Zepp, R.G. (1995) Photochemical production of dissolved inorganic carbon from terrestrial organic matter: Significance to the oceanic organic carbon cycle. Geophys. Res. Lett. 22, 417-420.

Moore, R.M., Burton, J.D., Williams, P.J.L. and Young, M.L. (1979) The behaviour of dissolved organic material, iron and manganese in estuarine mixing. Geochim. Cosmochim. Acta 43, 919-926.

Moos, S.B. and Boyle, E.A. (2018) Determination of accurate and precise chromium isotope ratios in seawater samples by MC-ICP-MS illustrated by analysis of SAFe Station in the North Pacific Ocean. Chem. Geol. 511, 481-493.

Nakayama, E., Kuwamoto, T., Tsurubo, S., Tokoro, H. and Fujinaga, T. (1981) Chemical speciation of chromium in sea water: Part 1. Effect of naturally occurring organic materials on the complex formation of chromium(III). Anal. Chim. Acta 130, 289-294. 
Novak, M., Chrastny, V., Cadkova, E., Farkas, J., Bullen, T.D., Tylcer, J., Szurmanova, Z., Cron, M., Prechova, E., Curik, J., Stepanova, M., Pasava, J., Erbanova, L., Houskova, M., Puncochar, K. and Hellerich, L.A. (2014) Common occurrence of a positive $\delta 53 \mathrm{Cr}$ shift in central European waters contaminated by geogenic/industrial chromium relative to source values. Environ. Sci. Technol. 48, 6089-6096.

Paulukat, C., Døssing, L.N., Mondal, S.K., Voegelin, A.R. and Frei, R. (2015) Oxidative release of chromium from Archean ultramafic rocks, its transport and environmental impact - A Cr isotope perspective on the Sukinda valley ore district (Orissa, India). Appl. Geochem. 59, 125-138.

Paulukat, C., Gilleaudeau, G.J., Chernyavskiy, P. and Frei, R. (2016) The Cr-isotope signature of surface seawater - A global perspective. Chem. Geol. 444, 101-109.

Pereira, N.S., Voegelin, A.R., Paulukat, C., Sial, A.N., Ferreira, V.P. and Frei, R. (2015) Chromium-isotope signatures in scleractinian corals from the Rocas Atoll, Tropical South Atlantic. Geobiology 14, 54-67.

Planavsky, N.J., Reinhard, C.T., Wang, X., Thomson, D., McGoldrick, P., Rainbird, R.H., Johnson, T., Fischer, W.W. and Lyons, T.W. (2014) Low Mid-Proterozoic atmospheric oxygen levels and the delayed rise of animals. Science 346, 635-638.

Reinhard, C.T., Planavsky, N.J., Robbins, L.J., Partin, C.A., Gill, B.C., Lalonde, S.V., Bekker, A., Konhauser, K.O. and Lyons, T.W. (2013) Proterozoic ocean redox and biogeochemical stasis. Proceedings of the National Academy of Sciences 110, 53575362.

Rigaud, S., Radakovitch, O., Couture, R.-M., Deflandre, B., Cossa, D., Garnier, C. and Garnier, J.-M. (2013) Mobility and fluxes of trace elements and nutrients at the sediment-water interface of a lagoon under contrasting water column oxygenation conditions. Appl. Geochem. 31, 35-51.

Saputro, S., Yoshimura, K., Matsuoka, S., Takehara, K., Narsito, Aizawa, J. and Tennichi, Y. (2014) Speciation of dissolved chromium and the mechanisms controlling its concentration in natural water. Chem. Geol. 364, 33-41.

Scheiderich, K., Amini, M., Holmden, C. and Francois, R. (2015) Global variability of chromium isotopes in seawater demonstrated by Pacific, Atlantic, and Arctic Ocean samples. Earth. Planet. Sci. Lett. 423, 87-97.

Schoenberg, R., Zink, S., Staubwasser, M. and Blanckenburg, F.v. (2008) The stable $\mathrm{Cr}$ isotope inventory of solid Earth reservoirs determined by double spike MC-ICP-MS. Chem. Geol. 249, 294-306. 
699

700

701

702

703

704

705

706

707

708

709

710

711

712

713

714

715

716

717

718

719

720

721

722

723

724

725

726

727

728

729

730

731

732

Shigematsu, T., Gohda, S., Yamazaki, H. and Nishikawa, Y. (1977) Spectrophotometric Determination of Chromium (III) and Chromium (VI) in Sea Water. Bull. Inst. Chem. Res. 55, 429-440.

Sholkovitz, E.R., Boyle, E.A. and Price, N.B. (1978) The removal of dissolved humic acids and iron during estuarine mixing. Earth. Planet. Sci. Lett. 40, 130-136.

Sikora, E.R., Johnson, T.M. and Bullen, T.D. (2008) Microbial mass-dependent fractionation of chromium isotopes. Geochim. Cosmochim. Acta 72, 3631-3641.

Stookey, L.L. (1970) Ferrozine---a new spectrophotometric reagent for iron. Anal. Chem. 42, 779-781.

Sun, Z., Wang, X. and Planavsky, N. (2019) Cr isotope systematics in the Connecticut River estuary. Chem. Geol. 506, 29-39.

Toma, J., Holmden, C., Shakotko, P., Pan, Y. and Ootes, L. (2019) Cr isotopic insights into ca. $1.9 \mathrm{Ga}$ oxidative weathering of the continents using the Beaverlodge Lake paleosol, Northwest Territories, Canada. Geobiology 17, 467-489.

Wu, W., Wang, X., Reinhard, C.T. and Planavsky, N.J. (2017) Chromium isotope systematics in the Connecticut River. Chem. Geol. 456, 98-111.

Zink, S., Schoenberg, R. and Staubwasser, M. (2010) Isotopic fractionation and reaction kinetics between $\mathrm{Cr}(\mathrm{III})$ and $\mathrm{Cr}(\mathrm{VI})$ in aqueous media. Geochim. Cosmochim. Acta 74, 5729-5745.

.


Figure 1. $\delta^{53} \mathrm{Cr}$ data for unpolluted rivers that drain into the ocean $\left({ }^{1} \mathrm{D}\right.$ 'Arcy et al. $2016 ;{ }^{2} \mathrm{Wu}$ et al. 2017; ${ }^{3} \mathrm{Frei}$ et al. 2014). Horizontal grey bar shows $\delta^{53} \mathrm{Cr}$ values for silicate crust; orange bar shows typical $\delta^{53} \mathrm{Cr}$ and $\mathrm{Cr}$ concentration of seawater (Bonnand et al., 2013; Scheiderich et al., 2015; Paulukat et al., 2016).

Figure 2. Sampling locations. Darker blue areas are intertidal flats.

Figure 3. Relationship between salinity and (A) dFe, (B) $\mathrm{Cr}_{\mathrm{T}}$, (C) $\mathrm{Cr}$ (III) concentration, (D) $\mathrm{Cr}(\mathrm{VI})$ concentration, and $(\mathrm{E}) \delta^{53} \mathrm{Cr}_{\mathrm{T}}$ (where error bars represent the external reproducibility; $0.11 \%$ ). (F) Relationship between $\mathrm{Cr}_{\mathrm{T}}$ and $\delta^{53} \mathrm{Cr}_{\mathrm{T}}$. Error bars for $\mathrm{Cr}_{\mathrm{T}}, \mathrm{Cr}(\mathrm{VI})$ and $\mathrm{Cr}(\mathrm{III})$ are $10 \%$. The March $20^{\text {th }}$ sample (B1) is excluded from A and from the trend lines in B-E because it is thought to be an outlier (see text for details).

Figure 4. Combined $\mathrm{O}_{2}$ profile for river sediment push cores $(n=3)$. Solid horizontal lines show the standard deviation from the mean value (none for -2.0 to $-0.2 \mathrm{~mm}$ as only one set of measurements taken). Dotted line is the sediment-water interface and dashed line is the average oxic-anoxic boundary depth.

Figure 5. (A) Modelled evolution of the $\delta^{53} \mathrm{Cr}$ value of $\mathrm{Cr}$ remaining in solution after reductive removal of $\mathrm{Cr}(\mathrm{VI})$ in sample B1 at $S=<0.5$, as a function of salinity. Sample B1 and B14 $\delta^{53} \mathrm{Cr}$ and $\mathrm{Cr}_{\mathrm{T}}$ values used to represent river and seawater endmembers respectively. River endmember $\delta^{53} \mathrm{Cr}$ for conservative mixing line $=-0.39 \%$ (see text for details). (B) Modelled evolution of $\mathrm{Cr}(\mathrm{VI}) / \mathrm{Cr}(\mathrm{III})$ for conservative mixing. River $(S=0)$ and seawater $(S=35)$ endmember $\mathrm{Cr}(\mathrm{VI})$ and $\mathrm{Cr}(\mathrm{III})$ values extrapolated from March data.

Figure 6. Schematic diagram showing potential mechanisms for $\mathrm{Cr}$ release and redox transformations within sediments/soils in the Beaulieu River catchment ( ${ }^{1}$ Frei et al. 2014; ${ }^{2}$ D'Arcy et al. 2016; ${ }^{3}$ Wu et al. 2017).

Figure 7. Modelled evolution of the $\delta^{53} \mathrm{Cr}$ value of $\mathrm{Cr}$ during conservative mixing between a seawater endmember with $\mathrm{Cr}_{\mathrm{T}}=1.6 \mathrm{nM}$ and $\delta^{53} \mathrm{Cr}=1.6 \%$, and river water endmembers with various $\mathrm{Cr}_{T}$ and $\delta^{53} \mathrm{Cr}$ values. 


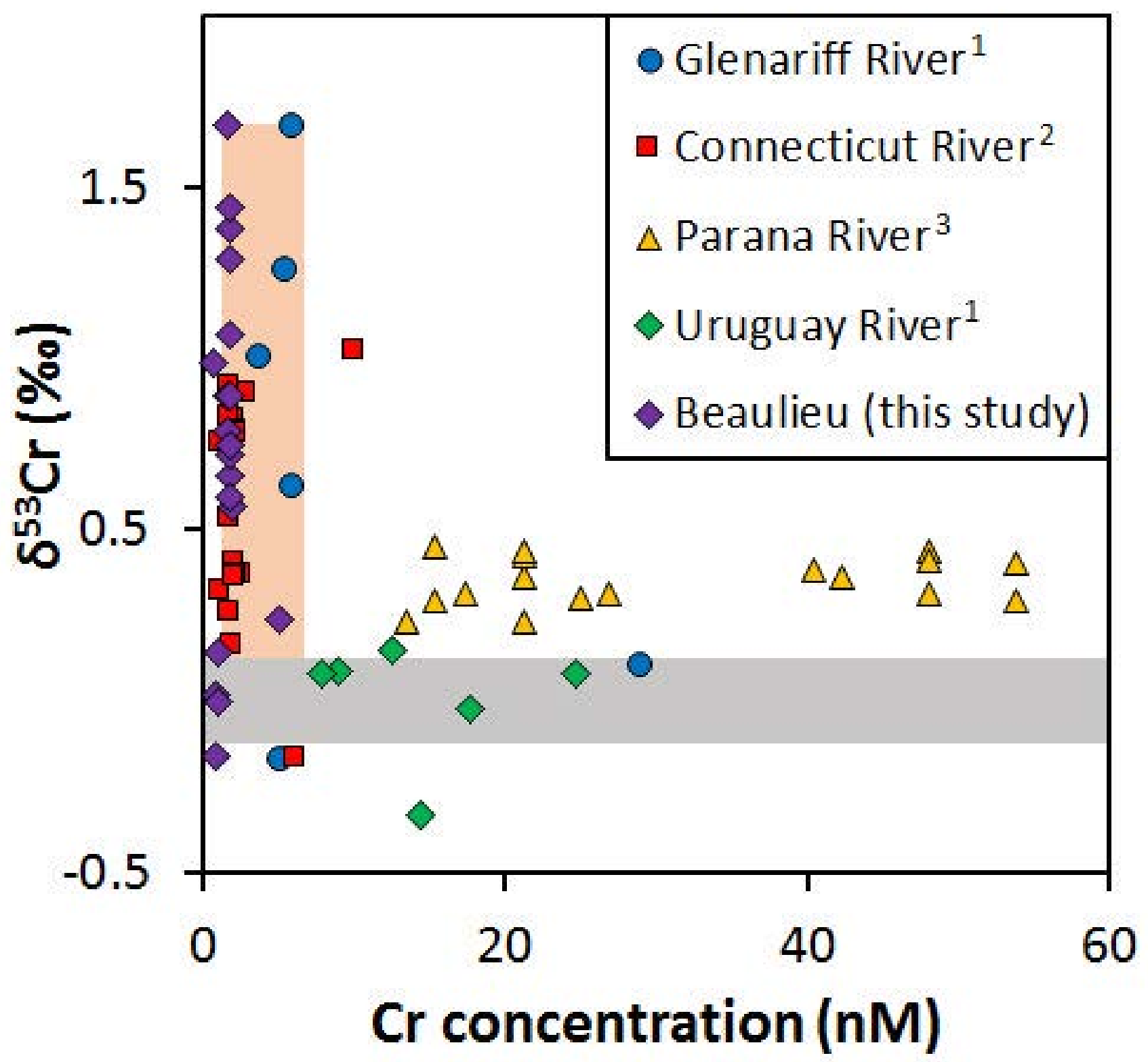



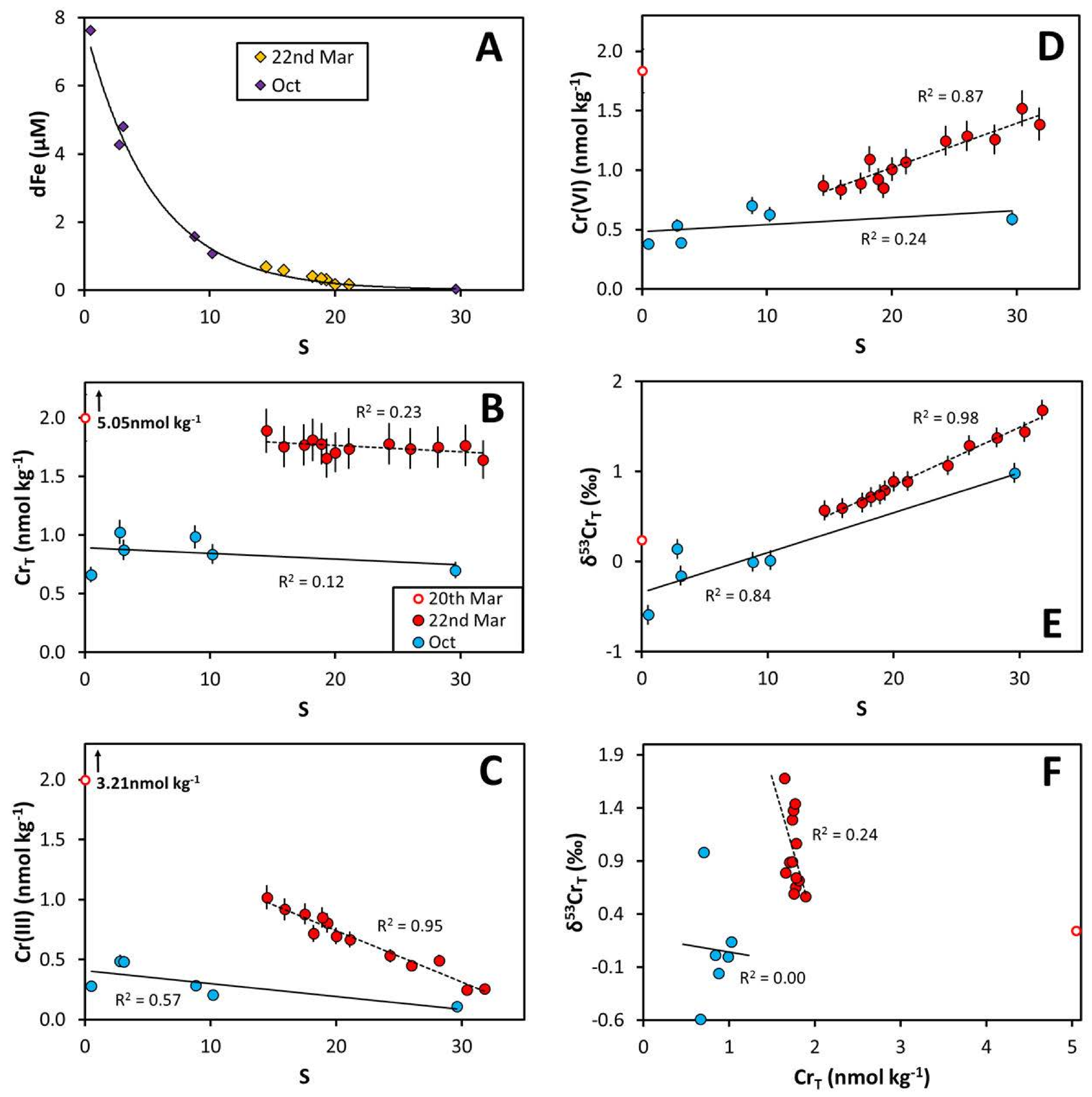


\section{$\mathrm{O}_{2}\left(\mu \mathrm{mol} \mathrm{L}^{-1}\right)$}

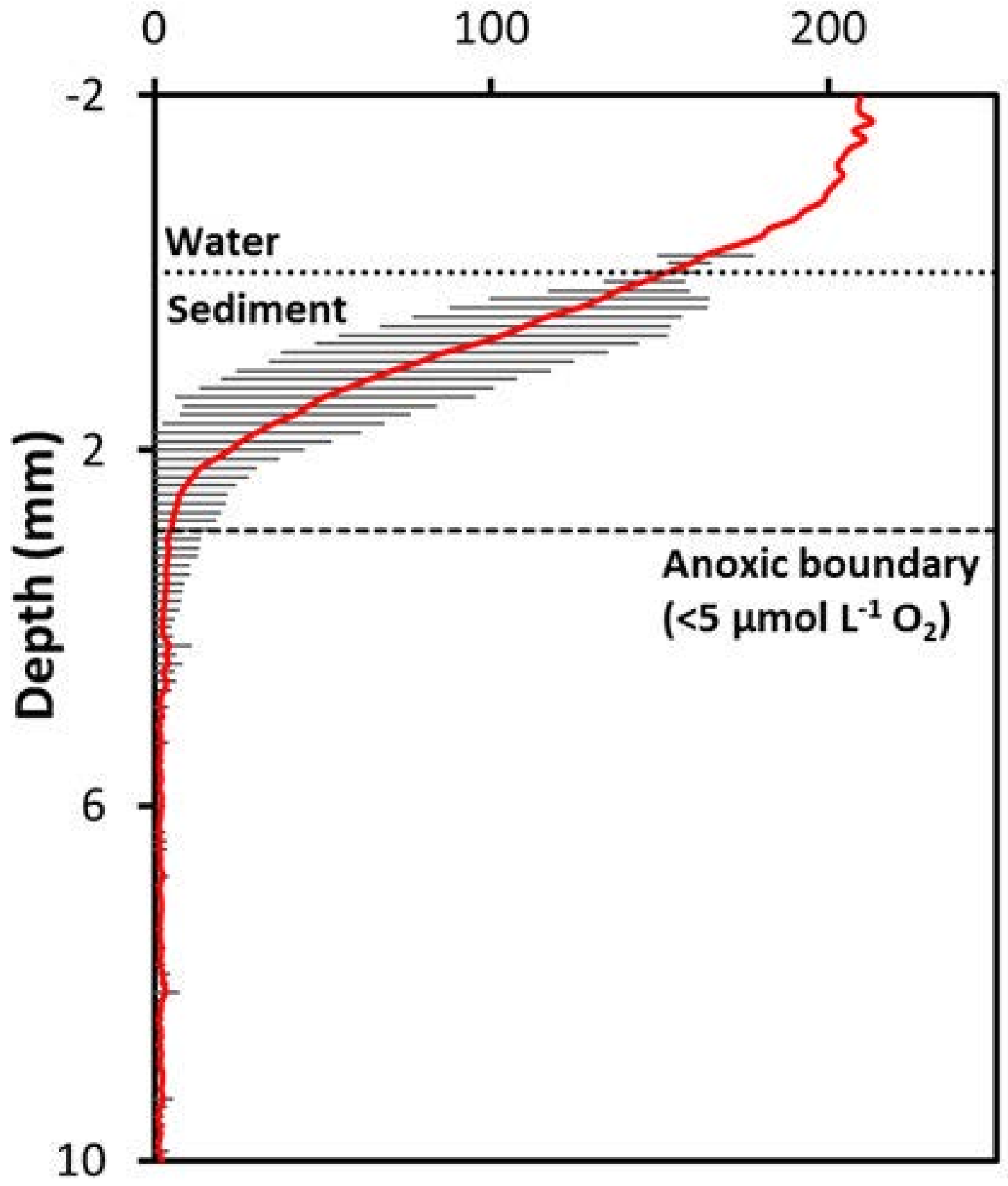



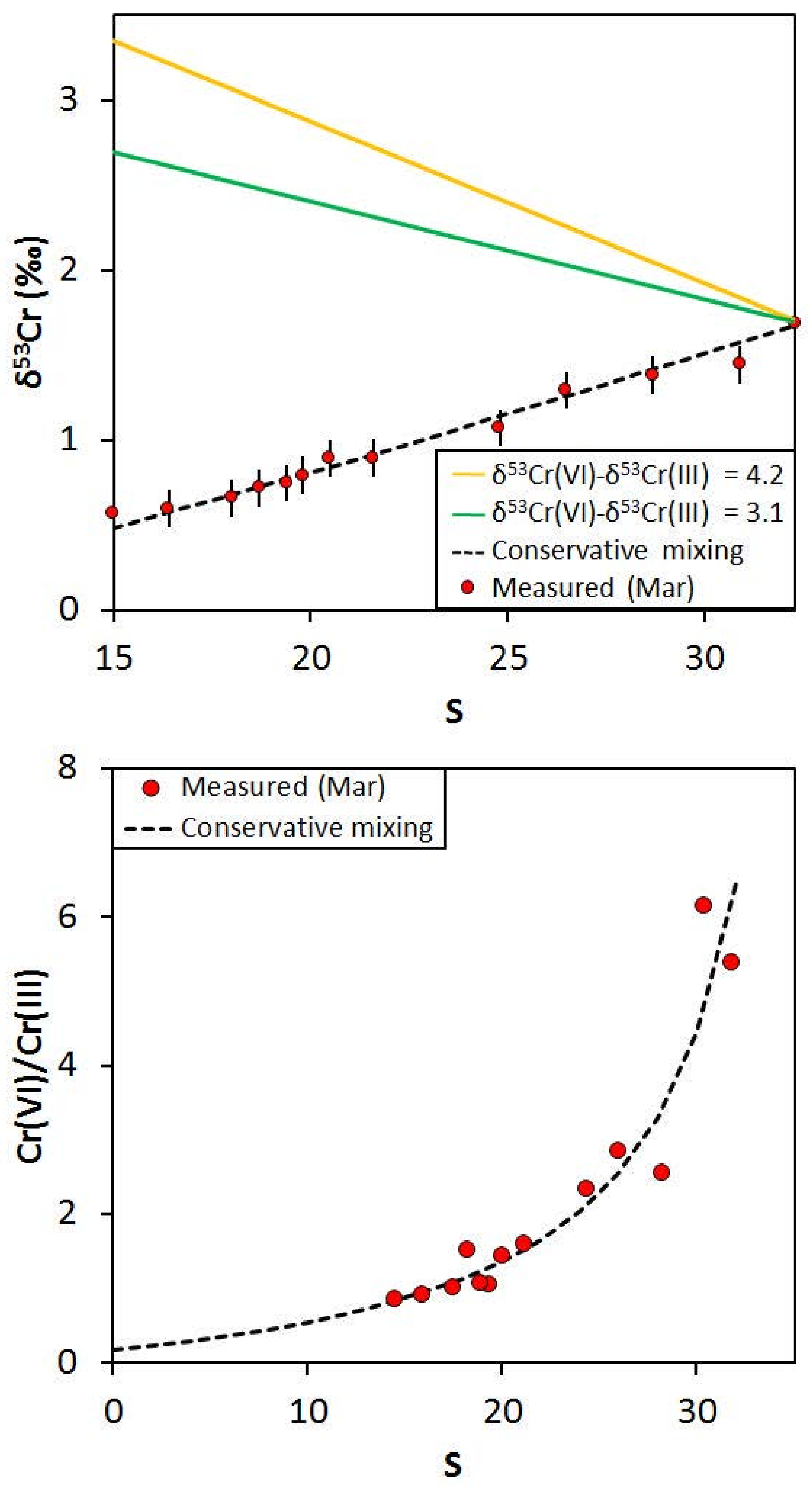


\section{RIVER}

$\delta^{53} \mathrm{Cr}=-0.59$ to $0.24 \%$ 。

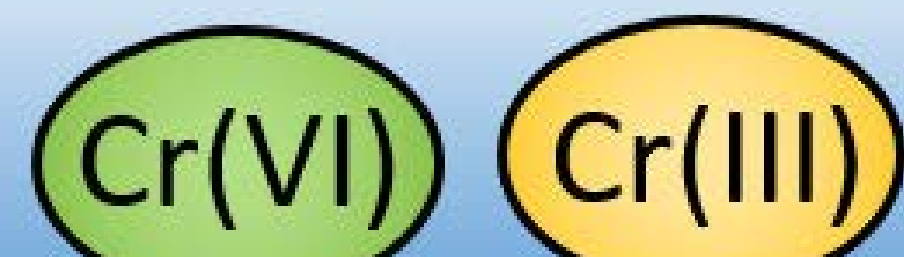

Photochemical dissociation

\section{$\mathrm{Cr}_{\mathrm{ORG}}$}

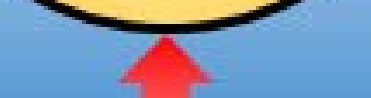

SEDIMENT

$\delta^{53} \mathrm{Cr}=-0.40$ to

$-0.10 \%_{0} 1,2,3$

Anoxic
Oxic Oxidation by $\mathrm{MnO}_{2}(\mathrm{Cr}(\mathrm{VI})$ Reduction by Fe(II)/organic material

Oxidation

by $\mathrm{MnO}_{2}$

Dissolution
PORE WATER $\delta^{53} \mathrm{Cr}=0.06$ to $0.13 \%$ 
Table 1. Results of analysis of $\mathrm{Cr}$ (III) concentration by $\mathrm{Fe}(\mathrm{III})$ pre-concentration and addition of ${ }^{53} \mathrm{Cr}$-enriched spike.

\begin{tabular}{|c|c|c|c|}
\hline Standard type & $\begin{array}{l}\text { Calculated } \mathrm{Cr}(\mathrm{III}) \\
\left(\mathrm{nmol} \mathrm{kg}^{-1}\right)\end{array}$ & $\begin{array}{l}\text { Measured } \mathrm{Cr}(\mathrm{III}) \\
(\mathrm{nmol} \mathrm{kg})\end{array}$ & Difference (\%) \\
\hline \multirow[t]{6}{*}{ Cr(III) only } & 11.00 & 11.23 & 2.0 \\
\hline & 10.77 & 11.19 & 3.8 \\
\hline & 10.58 & 10.48 & -2.0 \\
\hline & 10.04 & 10.44 & 1.9 \\
\hline & 10.49 & 10.78 & +2.8 \\
\hline & 10.45 & 10.23 & -2.1 \\
\hline $\mathrm{Cr}(\mathrm{III})+\mathrm{Cr}(\mathrm{VI})$ & 4.75 & 5.19 & 8.6 \\
\hline \multirow[t]{3}{*}{ (1:1 mix) } & 4.81 & 5.23 & 8.0 \\
\hline & 5.77 & 5.25 & -9.7 \\
\hline & 5.77 & 5.23 & -10.0 \\
\hline
\end{tabular}


Table 2. Composition of water samples from the Beaulieu River and Beaulieu estuary. BDL = Below Detection Limit.

\begin{tabular}{|c|c|c|c|c|c|c|c|c|c|c|}
\hline $\begin{array}{l}\text { Sampling } \\
\text { date }\end{array}$ & Sample & $\begin{array}{l}\text { Salinity } \\
\text { (S) }\end{array}$ & $\mathrm{pH}$ & $\begin{array}{c}\text { Temperature } \\
\left({ }^{\circ} \mathrm{C}\right)\end{array}$ & $\begin{array}{c}\delta^{53} \mathrm{Cr} \\
(\%)\end{array}$ & 2SD & $\begin{array}{c}\mathrm{Cr}_{\mathrm{T}} \\
\left.(\mathrm{nmol} \mathrm{kg})^{-1}\right)\end{array}$ & $\begin{array}{c}\mathrm{Cr}(\mathrm{III}) \\
\left(\mathrm{nmol} \mathbf{k g}^{-1}\right)\end{array}$ & $\begin{array}{c}\mathrm{Cr}(\mathrm{VI}) \\
\left.(\mathrm{nmol} \mathrm{kg})^{-1}\right)\end{array}$ & $\begin{array}{l}\mathrm{dFe} \\
(\mu \mathrm{M})\end{array}$ \\
\hline $\begin{array}{c}2^{\text {th }} \text { March } \\
2016\end{array}$ & B1 & 0.0 & 7.68 & 8.6 & 0.24 & 0.02 & 5.05 & 3.21 & 1.83 & 12.63 \\
\hline \multirow[t]{13}{*}{$\begin{array}{l}\text { 22 }{ }^{\text {nd }} \text { March } \\
2016\end{array}$} & B2 & 14.5 & 7.81 & 10.4 & 0.57 & 0.04 & 1.89 & 1.02 & 0.87 & 0.68 \\
\hline & B3 & 17.5 & 7.95 & 9.6 & 0.66 & 0.01 & 1.77 & 0.88 & 0.89 & 0.17 \\
\hline & B4 & 20.0 & 8.10 & 11.3 & 0.89 & 0.00 & 1.70 & 0.70 & 1.01 & 0.30 \\
\hline & B5 & 19.3 & 8.09 & 10.2 & 0.79 & 0.06 & 1.66 & 0.81 & 0.85 & 0.17 \\
\hline & B6 & 21.1 & 8.09 & 10.3 & 0.89 & 0.02 & 1.74 & 0.67 & 1.07 & 0.59 \\
\hline & B7 & 15.9 & 7.97 & 11.1 & 0.59 & 0.04 & 1.76 & 0.92 & 0.84 & 0.39 \\
\hline & B8 & 18.2 & 8.05 & 10.3 & 0.72 & 0.02 & 1.81 & 0.72 & 1.09 & 0.34 \\
\hline & B9 & 18.9 & 8.05 & 11.4 & 0.74 & 0.06 & 1.78 & 0.85 & 0.92 & BDL \\
\hline & B10 & 24.3 & 8.11 & 10.7 & 1.07 & 0.11 & 1.78 & 0.53 & 1.25 & BDL \\
\hline & B11 & 26.0 & 8.08 & 10.3 & 1.29 & 0.06 & 1.74 & 0.45 & 1.29 & BDL \\
\hline & B12 & 28.2 & 8.12 & 10.3 & 1.38 & 0.04 & 1.75 & 0.49 & 1.26 & BDL \\
\hline & B13 & 30.4 & 8.14 & 10.3 & 1.44 & 0.02 & 1.77 & 0.25 & 1.52 & BDL \\
\hline & B14 & 31.8 & 8.14 & 9.9 & 1.68 & 0.04 & 1.64 & 0.26 & 1.39 & BDL \\
\hline \multirow[t]{6}{*}{$\begin{array}{l}5^{\text {th }} \text { October } \\
2016\end{array}$} & B15 & 10.2 & 7.40 & 14.7 & 0.02 & 0.06 & 0.84 & 0.21 & 0.63 & 1.37 \\
\hline & B16 & 0.5 & 7.04 & 13.3 & -0.59 & 0.05 & 0.66 & 0.28 & 0.38 & 7.55 \\
\hline & B17 & 2.8 & 7.68 & 14.7 & 0.14 & 0.01 & 1.03 & 0.49 & 0.54 & 4.22 \\
\hline & B18 & 3.1 & 7.31 & 13.7 & -0.16 & 0.07 & 0.87 & 0.48 & 0.39 & 4.76 \\
\hline & B19 & 8.8 & 7.37 & 15.7 & 0.00 & 0.01 & 0.99 & 0.28 & 0.70 & 1.57 \\
\hline & B20 & 29.6 & 8.17 & 17.1 & 0.98 & 0.04 & 0.70 & 0.11 & 0.59 & BDL \\
\hline
\end{tabular}


Table 3. Results for UV irradiated samples.

\begin{tabular}{|c|c|c|c|c|c|c|}
\hline Sample & $\begin{array}{l}\mathrm{Cr}_{\mathrm{T}}+\mathrm{Cr}_{\mathrm{ORG}} \\
\left(\mathrm{nmol} \mathrm{kg}^{-1}\right)\end{array}$ & $\begin{array}{c}\text { CroRG } \\
\left(\mathrm{nmol} \mathrm{kg}^{-1}\right)\end{array}$ & $\begin{array}{c}\text { CroRG } \\
(\%)\end{array}$ & $\begin{array}{c}\delta^{53} \mathrm{Cr} \mathrm{Cr}_{\mathrm{T}}+ \\
\mathrm{Cr}_{\text {ORG }} \\
(\% \circ)\end{array}$ & 2SD & $\begin{array}{c}\delta^{53} \mathrm{Cr} \text { CroRG } \\
\text { calculated } \\
(\%)\end{array}$ \\
\hline B1 & 6.17 & 1.13 & 18 & 0.06 & 0.01 & -0.75 \\
\hline B2 & 2.52 & 0.63 & 25 & 0.40 & 0.01 & -0.11 \\
\hline
\end{tabular}

